\title{
Khyadag and Zunii Gol: Animal Art and the Bronze to Iron Age Transition in Northern Mongolia
}

\author{
W. W. Fitzhugh, J. Bayarsaikhan
}

For citation: Fitzhugh W.W., Bayarsaikhan J. Khyadag and Zunii Gol: Animal Art and the Bronze to Iron Age Transition in Northern Mongolia. Vestnik of Saint Petersburg University. History, 2021, vol. 66, issue 3, pp. 909-933. https://doi.org/10.21638/11701/spbu02.2021.313

The Late Bronze Age Mongolian culture known for its memorial deer stones and khirigsuur burials, the Deer Stone-Khirigsuur complex (hereafter DSK) dating to 1300-700 BCE, displays persistence over several hundred years. Radiocarbon dates from hearths and horse remains associated with these sites show little change in architecture, ritual practice, and iconography, giving the impression of an unchanging mortuary cultural regime. New research demonstrates that deer stones are memorials to recently deceased leaders that display distinctive features of personal identification within the unifying framework of an over-arching religious theme represented by deer-bird iconography. Despite continuity, the DSK complex is not monolithic. This paper presents evidence for regional cultural and chronological variation in deer stone

William W. Fitzhugh - PhD (Anthropology), Curator of North American Archaeology, Smithsonian Institution, Arctic Studies Center, P.O.Box 37012, Department of Anthropology MRC-112, $10^{\text {th }}$ St. \& Constitution Ave, NW, Washington, D.C., 20013, USA; Fitzhugh@si.edu

Вильям В.Фиихью - PhD (Anthropology), куратор отдела археологии Северной Америки Смитсоновского института, Центр арктических исследований, 37012, Отдел антропологии МRC112, США, 20013, округ Колумбия, Вашингтон, 10-я ул. и авеню Конституции; Fitzhugh@si.edu

Jamsranjav Bayarsaikhan - PhD (Anthropology), Research Center Director, National Museum of Mongolia, 1, Tourist st., Ulaanbaatar, 14201, Mongolia; jabayarsaikhan@gmail.com

Жамсранжав Баярсайхан - $\mathrm{PhD}$ (Anthropology), директор Научно-исследовательского центра, Национальный музей Монголии, Монголия, 14201, Улан-Батор, Туристская ул., 1; jabayarsaikhan@gmail.com

We would like to express our gratitude to P.DePriest, H.F.Beaubien, and V.Karas from the Smithsonian's Museum Conservation Institute who contributed to the analysis of Khyadag East slag and deer stone scanning; to B. Betz who managed field report production; to B. Betz and J. Clark who created maps; to our Mongolian and American field teams, drivers, and logistic assistants who played key roles, as did many scholars whose studies of deer stone and Bronze Age we depended upon. The Deer Stone Project has been a collaboration between the Smithsonian Arctic Studies Center and the Mongolia National Museum. Radiocarbon dates were provided by Beta Analytic Inc., and slag analysis was done by the Smithsonian Museum Conservation Institute.

Хотелось бы выразить благодарность П.ДеПрист, Х. Ф. Бобиен и В. Карас из Смитсоновского института музейной консервации, внесшим вклад в сканирование оленных камней Восточного Хядага; Б. Бец, руководившей составлением полевых отчетов; Б. Бец и Дж. Кларку, создавшим карты; нашим монгольским и американским полевым группам, водителям и помощникам по логистике; а также всем ученым, на чьи исследования оленных камней и эпохи бронзового века мы опирались в своей работе. Проект явился результатом длительного сотрудничества между Центром арктических исследований Смитсоновского института и Национальным музеем Монголии. Радиоуглеродные датировки были выполнены Beta Analytic Inc., а анализ шлаков проведен Смитсоновским институтом музейной консервации.

(C) St. Petersburg State University, 2021 
art and ceremonial activity based on research at the Khyadag and Zunii Gol sites in northcentral Mongolia. Areal excavation, detailed survey, and recording of deer stone art revealed the presence at Khyadag of a new class of miniature deer stones and evidence of copper smelting, and at Zunii Gol - an unusual khirigsuur associated with a deer stone carrying elements of Scytho-Saka animal style art. These data indicate geographic and chronological overlap in V.V.Volkov's deer stone types and changes in deer stone art and khirigsuur ritual in the later period of the DSK complex. In the future, emphasis needs to be given to broad excavation strategies that explore the contextual history of individual DSK sites, dating of Volkov's Type II and III deer stones, and regional comparisons with Xinjiang, Baikal, and the Mongolian and Gornyi Altai.

Keywords: Mongolia, Bronze Age, deer stone, archaeology, animal style art, Scythian, monument, mortuary ritual.

\title{
Хядаг и Зуны-Гол: анималистическое искусство и переход от эпохи бронзы к железному веку в Северной Монголии
}

\author{
В. В. Фиихью, Ж. Баярсайхан
}

Для цитирования: Fitzhugh W. W., Bayarsaikhan J. Khyadag and Zunii Gol: Animal Art and the Bronze to Iron Age Transition in Northern Mongolia // Вестник Санкт-Петербургского университета. История. 2021. Т.66. Вып. 3. С. 909-933. https://doi.org/10.21638/11701/spbu02.2021.313

Культура позднего бронзового века Монголии, известная комплексом, состоящим из погребальных оленных камней и захоронений «хиригсуур», датируемым 1300-700 гг. до н.э., сохранялась на протяжении нескольких сотен лет. Радиоуглеродные даты, полученные из заполнений очагов и костных остатков лошадей, относящиеся к данным объектам, указывают на слабую изменчивость конструкций, ритуальной практики, иконографии и создают впечатление неизменности погребальной обрядности, сохраняющейся на протяжении длительного времени. В новом исследовании показано, что оленные камни являются памятниками реально существовавшим вождям. Указанные изображения обладают отличительными чертами, на основании которых возможны личные идентификаци в рамках всеобъемлющей религиозной темы, представленной иконографией оленей и птиц. Несмотря на преемственность, комплекс оленных камней и захоронений не однороден. В этой статье представлены подтверждения региональных культурных и хронологических различий в искусстве оленных камней и обрядах, выявленные на стоянках Хядаг и Зуны-Гол на севере центральной Монголии. Масштабные раскопки, подробное обследование художественных композиций оленных камней выявили присутствие в Хядаге нового класса миниатюрных оленных камней и свидетельств плавки меди. Кроме того, важное открытие сделано в Зуны-Гол, где обнаружено необычное захоронение «хиригсуур», связанное с оленным камнем, имеющим черты скифо-сакского звериного стиля. Эти данные указывают на географическое и хронологическое совпадение типов оленных камней по классификации В. В. Волкова, с изменениями, зафиксированными в их декоре и в обряде «хиригсуур» в более поздний период. В будущем необходимо сделать упор на стратегию раскопок широкой площадью для исследования контекстуальной истории отдельных районов распространения комплексов оленных камней и захоронений, датировании оленных камней II и III типа по классификации Волкова и провести сравнительный анализ с подобными же древностями, известными в соседних регионах - Синьцзянском, Байкальском, Монгольском и Горном Алтае.

Ключевые слова: Монголия, эпоха бронзы, оленные камни, археология, искусство звериного стиля, скифы, сооружения, погребальная обрядность. 


\section{Introduction}

When Mongolia emerged from behind the "Iron Curtain" in the early 1990s, the world was amazed to discover world-class monumental art from its ancient past. Mongolia was better known for its $13^{\text {th }}$ century Mongolian empire, so scholars were surprised at finding an early society of nomads who produced anthropomorphic megaliths engraved with graceful figures of flying deer with flowing antlers (Figs. 1, 2). Most Russian scholars such as Okladnikov, Dikov, Volkov, Novgorodova, Savinov, and others who had studied deer stones since the 1930s believed that the iconic deer image was an Iron Age derivative of Scytho-Saka art. Although some question this view ${ }^{1}$, researchers from the Smithsonian and the National Museum of Mongolia have radiometrically dated deer stones to 1300-700 BP, which precedes the Pazyryk, Saka, and Scythian periods by several hundred years. At present, Mongolia's deer stones are among the earliest examples of megaliths and animal style art known from the steppes of Central Asia.

Between 2001 and 2009 the Smithsonian Institution and Mongolian National Museum conducted surveys and excavations at Late Bronze Age (LBA) deer stone and khirigsuur (stone-mounded burial) monuments ${ }^{2}$. The LBA was the time when metallurgy was introduced; horses were mounted for riding and chariot use; and ritual ceremony and monument building transformed the steppe landscape for the first time. Social complexity increased; domestic animals fueled economies; trade and external connections flourished; and human and domestic animal populations grew dramatically. Much of what is known from this period comes from deer stone and mortuary contexts because domestic sites are rarely found due to the faint traces of nomadic settlements.

Mongolian deer stones and khirigsuurs have been investigated for more than one hundred years ${ }^{3}$ but until recently received little systematic research and were studied pri-

1 Tseveendorj D. Some Deer Stone Stelas found in Mongolia // Studia Archeologica. 1979. T.VII, Fasc. 13. P. 36-85; Jacobson E. The Deer Goddess of Ancient Siberia: A Study in the Ecology of Belief. Leiden; New York; Kuhn, 1993.

2 Bayarsaikhan J.: 1) Research issues on Ritual Component of Deer Stones and Khirigsuurs. Nomadic heritage Studies. Museum Nationale Mongoli. T.IX, Fasc. 6. Ulaanbaatar, 2009. P.41-62; 2) Mongolyn umard nutgijn bugan hushuud. Ulaanbaatar, 2017; Beaubien H. F., Karas B. V., Fitzhugh W. Documenting Mongolia's Deer Stones: Application of Three-Dimensional Digital Imaging Technology to Preservation // Scientific Research on the Sculptural Arts of Asia. Washington, 2007. P.133-142; Fitzhugh W. W.: 1) Pre-Scythian Khirigsuurs, Deer Stone Art, and Bronze Age Cultural Intensification in Northern Mongolia // New Directions in Steppe Archaeology: the Emergence of Complex Societies in the Third to First Millennium BCE. Cambridge, 2009. P. 378-411;2) Stone Shamans and Flying Deer of Northern Mongolia: Deer Goddess of Siberia or Chimera of the Steppe? // Arctic Anthropology. 2009. Vol.46 (1-2). P.72-88; 3) The Mongolian Deer Stone-Khirigsuur Complex: Dating and Organization of a Late Bronze Age Menagerie // Current Archaeological Research in Mongolia. Bonn, 2009. P. 183-199; The Deer Stone Project: Anthropological Studies in Mongolia 2002-2004 / eds W. W. Fitzhugh, J. A. Bayarsaikhan, P. Marsh. Washington; Ulaanbaatar, 2005; Fitzhugh W.W., Bayarsaikhan J. Mapping Ritual Landscapes in Bronze Age Mongolia and Beyond: Interpreting the Ideoscape of the Deer Stone-Khirigsuur Complex // Mapping Mongolia: Situating Mongolia in the World from Geologic Time to the Present. Philadelphia, 2005. P. 166-192; Turbat T., Bayarsaikhan J., Batsukh D., Bayarkhuu N. Jargalantyn amny bugan khushuud = Deer Stones of Jargalant Am. Ulaanbaatar, 2011.

3 Jacobson E. The Deer Goddess of Ancient Siberia; Jacobson-Tepfer E.: 1) Cultural Riddles: Stylized Deer and Deer Stones of the Mongolian Altai // Bulletin of the Asian Institute, New Series. 2001. Vol.15. P. 31-56; 2) The Hunter, the Stag, and the Mother of Animals: Image, Monument, and Landscape in Ancient North Asia. Oxford, 2015; Bayarsaikhan J. Mongolyn umard nutgijn bugan hushuud. 


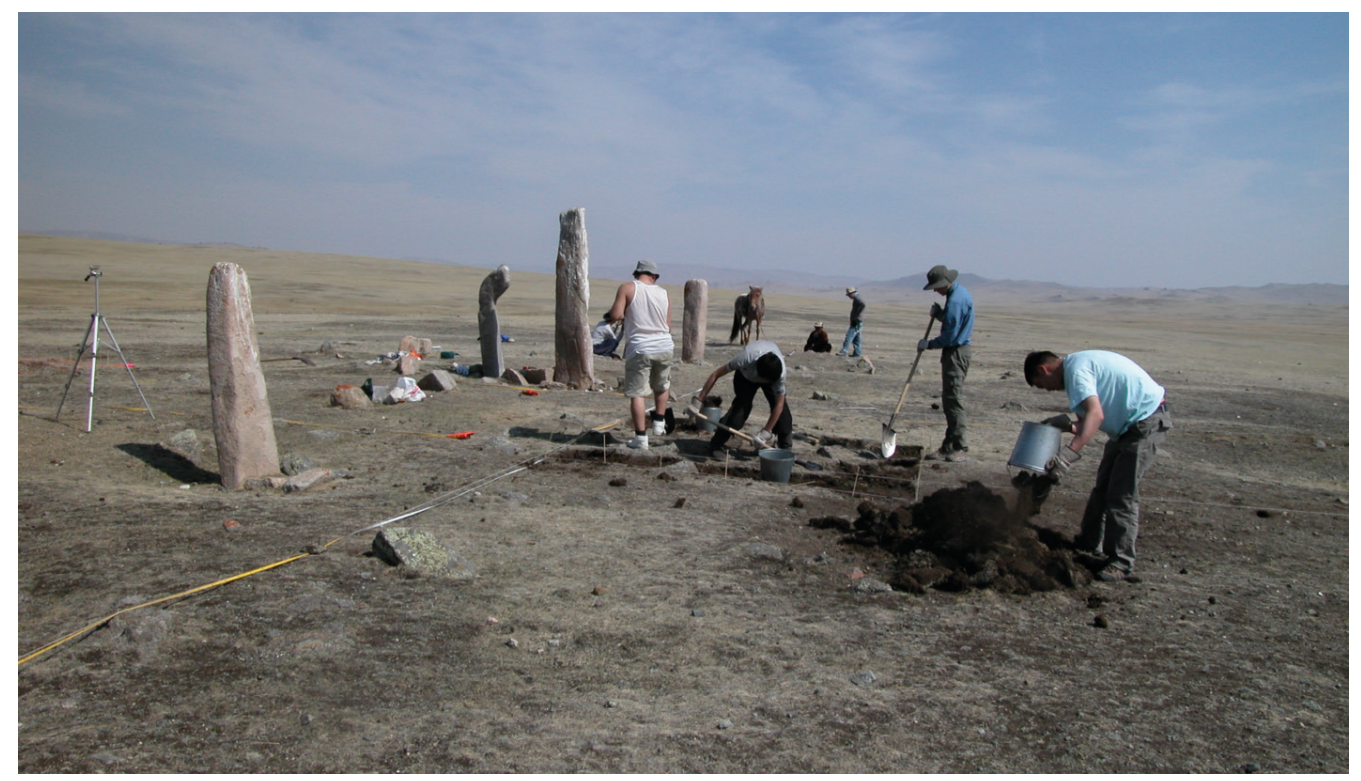

Fig. 1. Bor Khujiriin Gol site mapping and horse head excavation. Photo: W. Fitzhugh

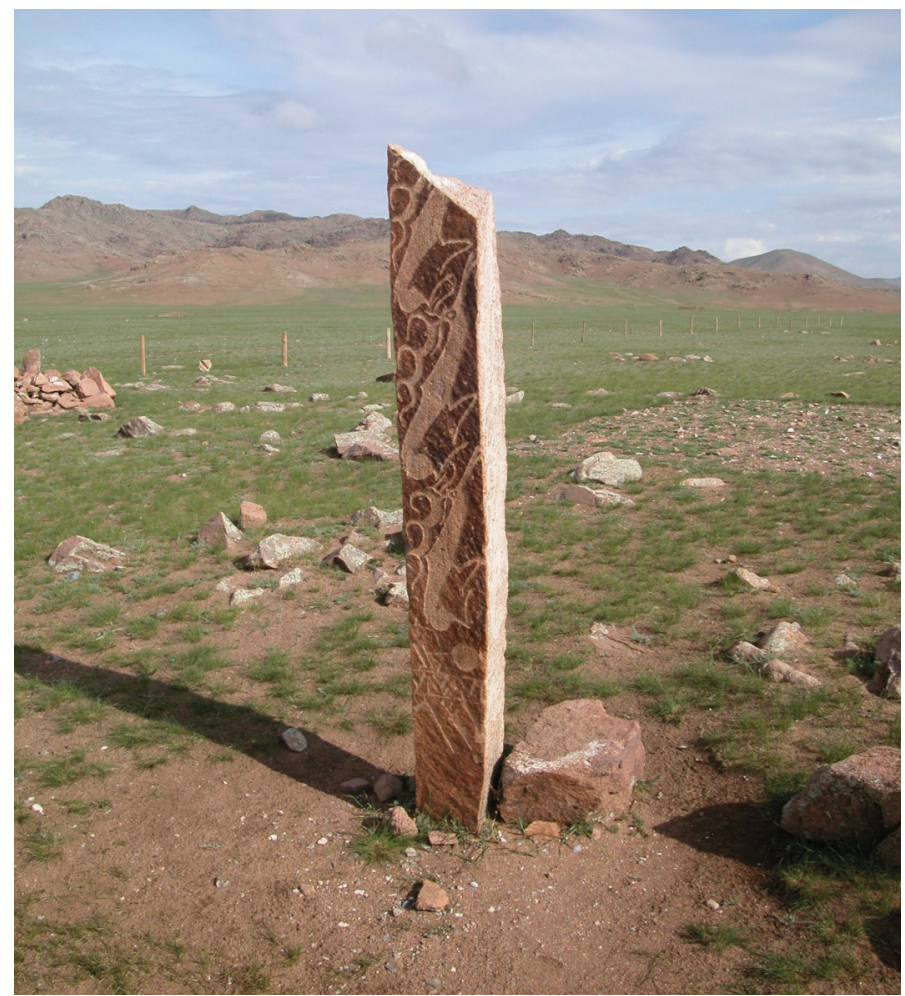

Fig. 2. Lightning damaged DS9 at Uushigiin Uvur displaying torso carvings of Mongolian deer and belt with attached weapons. Photo: W. Fitzhugh 
marily from an art-historical perspective ${ }^{4}$. Excavations produced few artifacts, and the frequent absence of human remains suggested that khirigsuurs functioned as ceremonial sites rather than burials, and that deer stones and khirigsuurs might have been created by different periods and cultures. Further questions arose in deer stone art. While some scholars saw similarities with Siberian Animal Style art, most assumed deer stone art was a derivative offshoot. No other type of art or image was known from Deer Stone-Khirigsuur (DSK) complex. The Mongolian-American Deer Stone project was initiated to investigate the date, function, and relationship between different types of deer stones and their art.

One of the problems associated with deer stone research has been the consistency of its style and structure. Once DSK chronology became secure ${ }^{5}$, scholars were confronted with the lack of any discernible changes in deer stone art or site organization, or in khirigsuur mortuary ritual over their their 600-year existence. It seemed that the DSK period and its art emerged full-blown around 1300-1400 BCE and continued with little change until 700 BCE. While the appearance of deer stone art prior to the Scytho-Saka horizon style cannot be disputed, its origin, regional relationships, and even stylistic and architectural change within the late DSK period are difficult to identify.

This paper presents data from two DSK sites investigated by the Mongolian-American Deer Stone Project. Elaborating on the pioneering work of V. V. Volkov and Novgorodova, we investigated scores of sites in northern Mongolia. Initial work focused on dating deer stone and khirigsuur monuments after we had found that sacrificial horse remains could be a direct indicator of the date of these sites.

The new DSK dates raised questions about origins, development, and transition to Iron Age cultures:

1. What could areal excavation of deer stone sites reveal about their function and organization?

2. What do new data show about the meaning, geography, and chronology of Volkov's three deer stone types?

3. Can regional and/or chronological variation be identified within Volkov's "Mongolian" or "classic" (Type I) deer stones?

4. Can deer stones provide some information about the transition from the Late Bronze to Early Iron Age?

These questions are considered after the general description of deer stones and excavation data from Khyadag and Zunii Gol are provided.

${ }^{4}$ Okladnikov A.P. Olennyi kamen s reki Ivolgi // Sovetskaia arkheologiia. 1954. Vol.19. P.207-220; Dikov N. N. Bronzovyi vek Zabaikal'ia. Ulan-Ude, 1958; Volkov V. V. Olennye kamni Mongolii. Moscow, 2002; Khudiakov Y.S. Khereksury i olennye kamni // Arkheologiia, Etnografia i Antropologiia Mongolii. Novosibirsk, 1987. P. 136-162; Novgorodova E. A. Drevniaia Mongoliia (nekotorye problemy khronologii i etnokul'turnoi istorii). Moscow, 1989; Savinov D. G. Olennye kamni v kul'ture kochevnikov Evrazii. St. Petersburg, 1994; Miniaev S. On the Interpretation of Certain Images on Deer Stones // Silk Road. 2013. Vol.11. P. 54-59; Magail J. Les stèles ornées de Mongolie dites 'pierres à cerfs', de la fin de lâge du Bronze // Statues-menhirs et pierres levées du Néolithique à aujourd'hui. Saint-Pons-de-Thomières, 2015. P. 89101; Jacobson E. Petroglyphs and the Qualification of Bronze Age Mortuary Archaeology // Archaeology, Ethnology, and Anthropology of Eurasia. 2002. Vol. 3 (11). P. 32-47; Jacobson-Tepfer E. The Hunter, the Stag, and the Mother of Animals.

${ }^{5}$ Fitzhugh W. W. The Mongolian Deer Stone-Khirigsuur Complex. P. 183-199; Taylor W. T., Wilkin S., Wright J. et al. Radiocarbon Dating and Cultural Dynamics Across Mongolia's Early Pastoral Transition // PLOS ONE. 2019. Vol. 14 (11). Article-e0224241. 


\section{Deer Stone Types and Description}

V.V. Volkov documented and catalogued over 350 deer stones in north-central Mongolia, the well-watered region that later became the heartland for a succession of Mongolian empires. Deer stones are also found in western (Altai) Mongolia, where Volkov documented 30 deer stones, and outliers occur in South Siberia, Baikal, Gornyi Altai, eastern Kazakhstan, and Xinjiang, where 74 are known ${ }^{6}$. Volkov rarely probed for buried stones, and our surveys and recent work by Russian, Japanese, and Chinese archaeologists have uncovered many fallen and buried stones, making it likely that the total number exceeds 1300 stelas $^{7}$.

Deer stones are square or rectangular in cross-section and vary in size from 0.5 to 3-4 m tall. Central Mongolian deer stones are made of granite, basalt, or diorite, while those in western Mongolia are often made of slate or schist and have been heavily vandalized. The stelae are anthropomorphic, and the carved images have standardized shapes and formats. The head portion of the "Classical Mongolian" (Type I, see: Fig. 3a) deer stone may rarely display a human face, or more frequently two or three slash marks (///, //) that are usually seen on Type II and III deer stones. Some Type I deer stones have highly polished face areas that originally had painted portraits ${ }^{8}$. Ears are rarely seen and are usually represented by earring hoops. The torso area is engraved with a beaded necklace, and the chest with one or nested ranks of flying or leaping deer with folded legs. This image represents the red deer or maral (Cervus elaphus sibericus) that can be identified by its wave-like antlers. The deer's 'head' is represented not as a stag but rather as a bird with a large round eye and an elongated, partly open bill, identifying this creature as a transformed being. A pentagonal shield emblem with internal chevron bars, a shaman's mirror, and other items are depicted on the torso. The waist often features a patterned belt to which tools and weapons are attached by cords. Legs and arms are almost never shown. The necklace, belt, and carvings sometimes extend around all four sides of the stone. Deer stones were erected with the face, chest, and most of the weapons facing east or southeast, probably so that the figure could greet the rising sun. Earrings are on the north and south sides, and the rear side showing the pentagonal shield faces west. Shadow effects highlight the carvings on different sides as the sun passes daily from east to west.

There is considerable amount of discussion in deer stone scholarship about what the images portray. Theories range from gods, to ancestors, or simply unknown warriors ${ }^{9}$. Modern research confirms that deer stones are representations of specific Late Bronze Age warriors or warrior/shaman leaders. Considering the tattooed bodies of warriors dating several hundred years later in frozen Pazyryk mounds ${ }^{10}$, it seems likely that the deer-bird

${ }^{6}$ Tsybiktarov A. Tsentral'naia Aziia v epokhu bronzy i rannego zheleza (problemy etnokul'turnoi istorii Mongolii i Iuzhnogo Zabaikal'ia serediny II - pervoi poloviny I tys. do n. e.) // Arkheologiia, etnografiia i antropologiia Evrazii. 2003. Vol. 13. P. 80-97; Kubarev V.D. Dva izvaianiia epokhi bronzy v Gornom Altae // Arkheologiia, etnografiia i antropologiia Evrazii. 2009. Vol. 37 (1). P.34; Guo W. The Excavation of the Huahaizi No. 3 Site in Qinghe County, Xinjiang // Chinese Archaeology. 2017. Vol. 17 (1). P. 151-162.

7 Bayarsaikhan J. Mongolyn umard nutgijn bugan hushuud; Hatakeyama T. The Tumulus and Stag Stones at Shiebar-kul in Xinjiang, China // Newsletter of Steppe Archaeology. 2002. Vol. 13. P. 1-8.

${ }^{8}$ Esin Y. N., Magail J., Rousseliere H., Walter P. Les peintures dans l'art pariétal de la culture Okuniev // Bulletin du Musée d’Anthropologie préhistorique de Monaco. 2014. No. 54. P. 163-183.

9 Miniaev S. On the Interpretation of Certain Images on Deer Stones. P. 54-59.

${ }^{10}$ Gryaznov M.P. Monumental'noe iskusstvo na zare skifo-sibirskikh kul'tur v stepnoi Azii // Tezisy konferentsii "Kontakty i vzaimodeistviia drevnikh kul'tur". Leningrad, 1981. P.21-24; Rudenko S. I. Kul'tura 

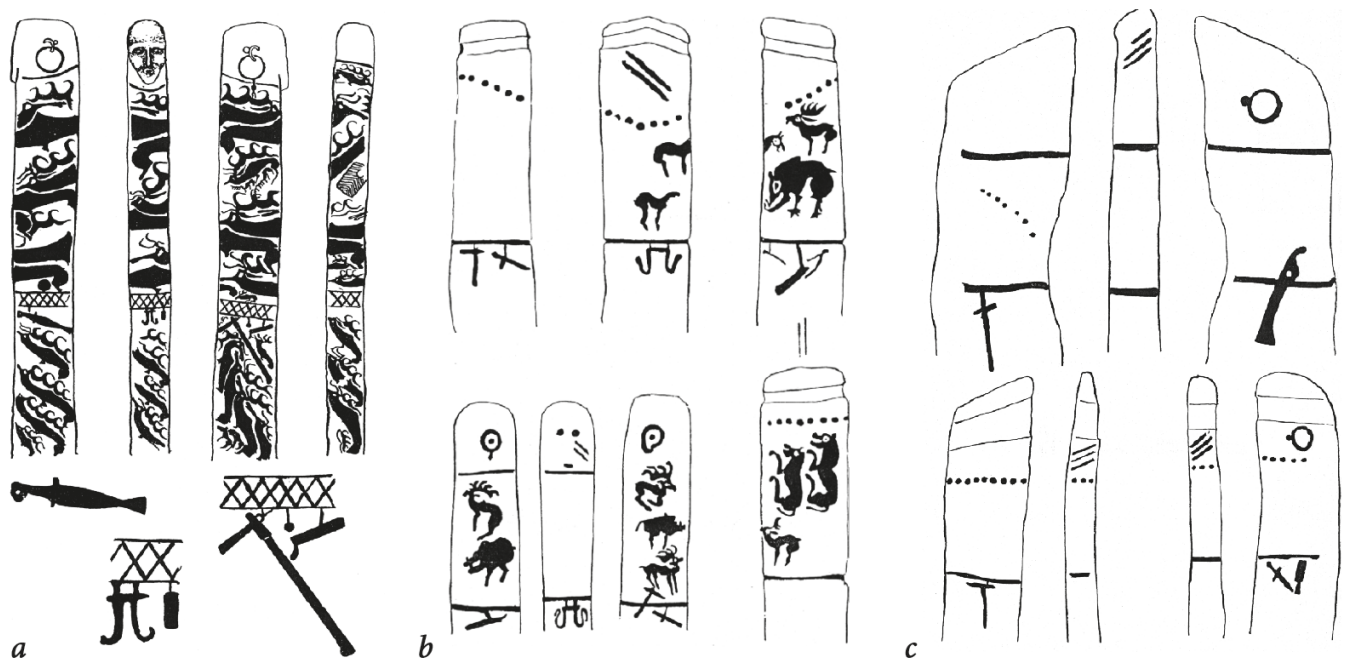

Fig. 3. Volkov's three deer stone types: $a$ - Type I Classical Mongolian Ushigiin Uvör DS14; $b-$ Type II Sayan-Altai, Doroljiin Am DS1; $c$ - Type III Eurasian, Targon Nuur DS1 (after [Volkov V. V., 1995, 2002])

motif and other emblems functioned as spiritual protective shields for these individuals. Physical manifestations of the pentagonal shield with chevron bars have been found as stone tablets in deer stone sites in Xinjiang ${ }^{11}$. While the deer image always takes the exact same form (as required of a codified religious emblem), their number, size, and orientation on deer stones varies on each stela, perhaps as these images were seen on living individuals. The deer are never shown interacting, and other than antlers, are gender-neutral. Belt patterns and the tool types represented on them: all differ from one stone to another as would be the case in real life.

Human remains and artifacts are not usually found with deer stones, and in central Mongolia individual deer stones have not been linked to khirigsuur burials, although this is common in the Altai Mountains where they are often built into khirigsuur constructions. Deer stones served as memorials to individuals who had sufficient power and respect to be enshrined for posterity in stone. Along with khirigsuurs, deer stones served to solidify the social, historical, cultural, and political structure of Late Bronze Age Mongolia by personifying and memorializing leaders and perpetuating their legacy in stone ${ }^{12}$. At sites with multiple deer stones, their lineal north-south arrangement may represent the historical sequence of past leaders.

Deer stones are surrounded by small stone features containing east-facing horse skulls and mandibles bundled together with neck vertebrae and hooves. Further away,

naseleniia gornogo Altaia v skifskoe vremia. Moscow; Leningrad, 1953; Jettmar K. Body-Painting and the Roots of the Scytho-Siberian Animal Style // The Archaeology of the Steppes: Methods and Strategies. Series minor. 1994. Vol.44. P.3-15; Polosmak N. V. Tatuirovka u pazyryktsev // Arkheologiia, etnografiia i antropologiia Evrazii. 2000. Vol. 4 (4). P.95-102.

11 Guo W. The Excavation of the Huahaizi... P. 151-162.

12 Fitzhugh W.W. Mongolian Deer Stones, European Menhirs, and Canadian Arctic Inuksuit: Collective Memory and the Function of Northern Monument Traditions // Journal of Archaeological Method and Theory. 2014. Vol. 24 (1). P. 149-187. 
most deer stone sites are surrounded by a ring of small circular hearths containing charcoal and burned bones of caprids (sheep/goat) and larger mammals. These same features and arrangement are also found at khirigsuur mounds, with horse heads buried east of the khirigsuur fence and hearth rings outside the fence west of the khirigsuur. The hearths were probably used to raise smoke from animal offerings to the gods, a practice noted by Herodotus at Scythian burials ${ }^{13}$, although there is a counter argument ${ }^{14}$. The iconic Mongolian deer is also found in Mongolian rock art near deer stone and khirgsuur sites.

Volkov, Novgorodova, Savinov, and Bayarsaikhan have made the most comprehensive studies of deer stone design elements. Volkov's deer stone types ${ }^{15}$ roughly conform to geography. Type I "classical" Mongolian deer stones (see: Fig. 3a) are both the most complex and the most stylized and occur in north-central Mongolia. Type II Sayan-Altai stones (see: Fig. $3 b$ ) have a simplified design featuring images of animals as well as deer and tools, all seen 'floating' on the torso. These stones are found around the mountainous fringes of western and northern Mongolia and in the Russian Altai and Xinjiang. Type III, the Eurasian type (see: Fig. 3c), the simplest, has only face slashes, necklace, and belt grooves. These stones are also found in western Mongolia, Xinjiang, and in small numbers in West Asia, southern Russia, around the northern part of the Black Sea, and rarely in Eastern Europe ${ }^{16}$. Type I stones date securely to 1300-700 BCE. Types II and III are not well-dated but appear to belong to the latter part of the DSK period (see below), and Type III stones can occur at Scythian burial sites in the Pontic region.

Our research supports Volkov's classification but finds that Type II and III stones are also present in the Type I area in central Mongolia where they probably overlap or postdate Type I stones by several hundred years. Type I deer stones in western Mongolia date to the same period as in central Mongolia. However, variation in deer stone art and khirigsuur ritual between central and western Mongolia suggests ethno-cultural differences within the wider DSK culture area. One of the most important differences is the absence of horse sacrifice in western sites and the incorporation of deer stones in khirigsuurs.

In the following sections of the article, we describe two sites that provide information on DSK site organization, function, chronology, and art. Of particular interest is recognition of the complexity and multi-function nature of deer stone sites. In addition, we note innovations in deer stone art that suggest regional variation and chronological development during the LBA as well as influence from Early Iron Age society and art from steppe cultures to the west.

${ }^{13}$ Bayarsaikhan J. Research issues on Ritual Component... P.41-62; Van Straten F.T. Hierà Kalá: Images of Animal Sacrifice in Archaic and Classical Greece. Leiden, 1995. P. 124, 131, 166-167; Naiden F. S. Smoke Signals for the Gods: Ancient Greek Sacrifice from the Archaic through Roman Periods. Oxford; New York, 2013.

14 Broderick L.G., Houle J.-L., Seitsonen O., Bayarsaikhan J. The Mystery of the Missing Caprines: Stone Circles at the Great Khirigsuur in the Khanuy Valley // Studia Archaeologica. 2014. Vol.XXXIV. P. 164-174.

15 Volkov V. V.: 1) Early Nomads of Mongolia // Nomads of the Eurasian Steppes in the Early Iron Age. Berkeley, 1995. P.319-332; 2) Olennye kamni Mongolii.

${ }_{16}$ Chlenova N.L. Olennye kamni kak istoricheskii istochnik. Novosibirsk, 1984; Hatakeyama T. The Tumulus and Stag Stones... P. 1-8; Olkhovskii V.S. Monumental'naia skul'ptura naseleniia zapadnoi chasti evraziiskikh stepei epokhi rannego zheleza. Moscow, 2005. 


\section{Khyadag Deer Stone Sites}

Khyadag is a grassy plain in Burentogtokh suum, Khuvsgul aimag, midway between Murun and Lake Erkhel that has two deer stone sites a few hundred meters apart. Khyadag West ( $\mathrm{N} 49^{\circ} 48,876$, E $\left.99^{\circ} 53,946^{\prime}\right)$ has four deer stones, three of which were standing in 2006, and Khyadag East (N 49 48.900', E 99 54.042') has nineteen deer stones, two of which were standing in 2007 (Fig. 4). The standing stones in both sites are made of coarse granite with eroded surfaces. Unlike most other deer stone sites, Khyadag had no khirigsuurs.
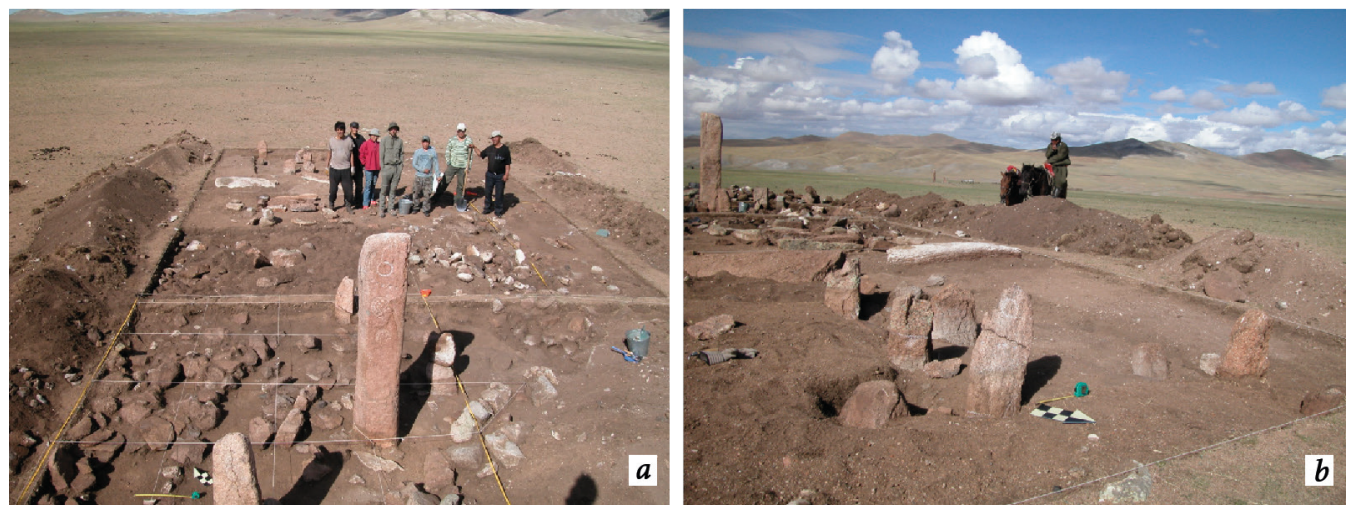

Fig. 4. Khyadag East showing: $a-$ areas 1-3 with DS1 and 3 in foreground, 2 and 4 to rear, miniature deer stones aligned north in upper left, viewed to north; $b$ - miniature Type III deer stones viewed to southwest. Photos: W. Fitzhugh

Khyadag East deer stones (Fig. 5) follow the format of Volkov's Eurasian Deer Stone Type III. All have earrings, pitted necklaces, face slashes, and belt grooves but rarely tools or animals. DS1 ${ }^{17}$ is $105 \mathrm{~cm}$ high and badly broken and spalled. Its east side has three forward slashes /// on the face and a belt groove around all four sides. The north side has a circle with a pendant at the top and three necklace pits (N. B.: reference to cardinal direction indicates the stone's original orientation as determined by face, earrings, and pentagonal motif markers). The south side has a pendant earring, six necklace pits, and a belt groove. The west side is illegible due to spalling. DS4 (B46, here and below, B\#\# refers to figure numbers in Bayarsaikhan's "Mongolyn umard nutgijn bugan hushuud" (2017)) is similar to DS1, $105 \mathrm{~cm}$ high with circle earrings, necklace pits, and a belt groove. DS3 (B44) is $198 \mathrm{~cm}$ tall and has the same markings with the addition of an unidentifiable implement on the north side belt. Other marks may have been present but have been lost to surface spalling. Its south side has two right-facing horses below the belt and two coiled felines below the necklace. DS 16-19 (B53-56) have similar markings. DS2, 5-10, and 16-19 (B45, 47-56), when not eroded, have earrings, necklace pits, and belt grooves and no other distinguishable marks except DS6 which has $\backslash$ face slashes, and DS16 which has an axe on its belt. The larger deer stones, DS4, 16, 17 (B46, 53-54), ca. 1.0-1.5 m tall, were found below the surface north of the standing stones. The markings on these stones are similar to DS1, 2.

\footnotetext{
17 See: Bayarsaikhan J. Mongolyn umard nutgijn bugan hushuud. Fig. 43.
} 

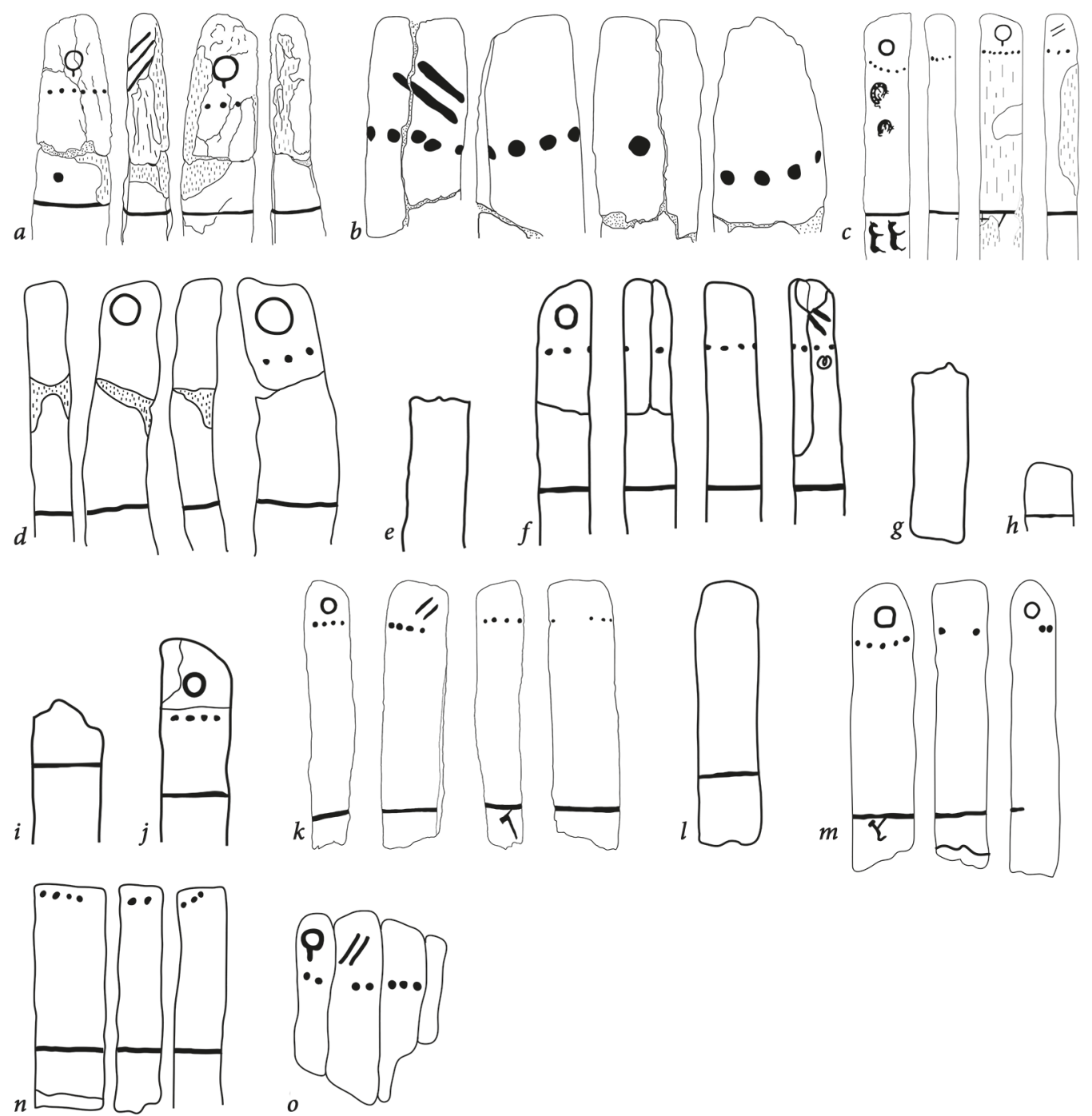

Fig. 5 (a-o). Khyadag East Deer Stones 1-20 [Bayarsaikhan J., 2017. Figs. 43-57]

The two standing stones align northeast/southwest magnetic. The large DS33 (Fig. 5c; B44) stands $198 \mathrm{~cm}$ above ground and is partly eroded. However, it retains its north and south side earring circles with hanging pendants, necklace pits around all four sides, has two forward slashes $(/ /)$ on the east 'face' side, and a belt band with at least one attached implement. Below the belt two horses are depicted standing sideways, heads up, facing east. The south side also features two coiled feline images facing east. This motif is rarely seen on deer stones but is a classic Scytho-Saka design element that may have been a later addition. The smaller standing deer stone DS1 (Fig. $5 a$; B43) has pendant earrings on its north and south sides, necklace pits all around, three forward slashes on its eastern face, and a mirror above a belt band without tools.

These deer stones stand in a complex of features including a $3 \times 6 \mathrm{~m}$ rectangular cobble pavement containing remains of butchered caprids, a horse sacrifice mound, four 
large buried deer stones (DS2, 4, 16, 17), and a series of vertical slabs broken off just above the surface of the ground. These slabs turned out to be miniature deer stones, DS5, 6, 7, 8 , 9, and 10 (see: Fig. $4 b)^{18}$, which were $2-3 \mathrm{~cm}$ thick, originally ranging from 30 to $60 \mathrm{~cm}$ high, and were set in a line running north from the standing deer stones. Images of Mongolian deer, other animals, and weapons were absent, but these stones had the essential markings (belt, necklace, earrings, and // or \ face slashes) of Volkov's Eurasian Type III deer stones. Flat slabs were found around the bases of some miniature deer stones, and below the slabs at DS1, 5, 6 there were small deposits of broken bones and bone splinters. In addition, DS5 had two snapped femurs of a small mammal, and DS6 had a ceramic pot fragment. These finds suggest that deer stone ritual may have included animal offerings besides horse heads.

The excavation provided no clue about the function of these miniature deer stones or why they and DS 1, 2 and 4 were broken. Lightning strikes and animal rubbing are hazards for standing deer stones, but at Khyadag East all except the largest, DS3, seem to have been purposefully damaged or destroyed. Their top fragments were found next to their bases in the Bronze Age cultural layer.

Khyadag deer stones stand out as unique among DSK heartland sites. Although being made clearly in DSK tradition, they lack elaborate decoration and are similar to Eurasian Type III deer stones that dominate in the Mongolian and Russian Altai ${ }^{19}$. We have no clear explanation other than noting that Khyadag East dates late in the DSK chronology and has a second post-DSK occupation associated with copper production.

While excavating Area A deer stones north of DS3, we discovered a layer that contained charcoal, burned pottery, slag, and pieces of flat metal-like fragments. One of the plate-like pieces was 3-4 mm thick and was curved like a vessel wall. Laboratory studies identified the material as copper production slag ${ }^{20}$. Some of the pottery had slag deposits on one side and an orange-fired surface on the other, suggestive of furnace lining. Two charcoal samples from this level dated cal. 800-400 BCE (see: List of radiocarbon dates from Khyadag East and West; Fig. 6). A horse tooth from beneath Feature 32, a sacrificial mound also found here, produced a similar date, which is late for most DSK horse dates, while another horse tooth from the nearby rectangular pavement dated ca. $800 \mathrm{BCE}$. The date of the bronze-charcoal layer corresponds with the Scytho-Saka period and the coiled felines on DS3. Khyadag East appears to have been a late DSK component that created many Eurasian Type III deer stones. Shortly after this occupation, the site became the fo-

List of radiocarbon dates from Khyadag East and West

\begin{tabular}{llllll}
\hline Khyadag E A3F32 & Erkhel/2008 & B-246620 AMS & tooth collag. & $2520 \pm 40 \mathrm{BP}$ & BP 2740-2470 \\
Khyadag E A2 midden & Erkhel/2008 & B-246621 RAD & charcoal & $2460 \pm 50 \mathrm{BP}$ & BP 2730-2350 \\
Khyadag E A2 midden & Erkhel/2008 & B-246622 RAD & charcoal & $2520 \pm 50 \mathrm{BP}$ & BP 2750-2440+ \\
Khyadag W. F1 & Erkhel/2008 & B-246623 AMS & bone collag. & $2610 \pm 40 \mathrm{BP}$ & BP 2870-2750 \\
\hline
\end{tabular}

Note: B-246622 Khyadag East A2 has a second intercept at BP 2410-237.

18 Cf. Ibid. P. 281.

19 Tishkin A.A. Advancing Archaeological Research of the Mongolioan Altai through the Scientific Study of Deer Stones: New Discoveries from Buyant Valley // Asian Perspectives. 2020. Vol. 59 (2). P. $453-$ 478.

20 Watson J., Goodman M., Speakman J. Slag Report for Finds from 2008 Deer Stone Project Field Season. Project no. 6249. Smithsonian Museum Conservation Institute. Appendix 1 // 2009 Mongolia Field Report. Washington, 2009. P.211-218. 


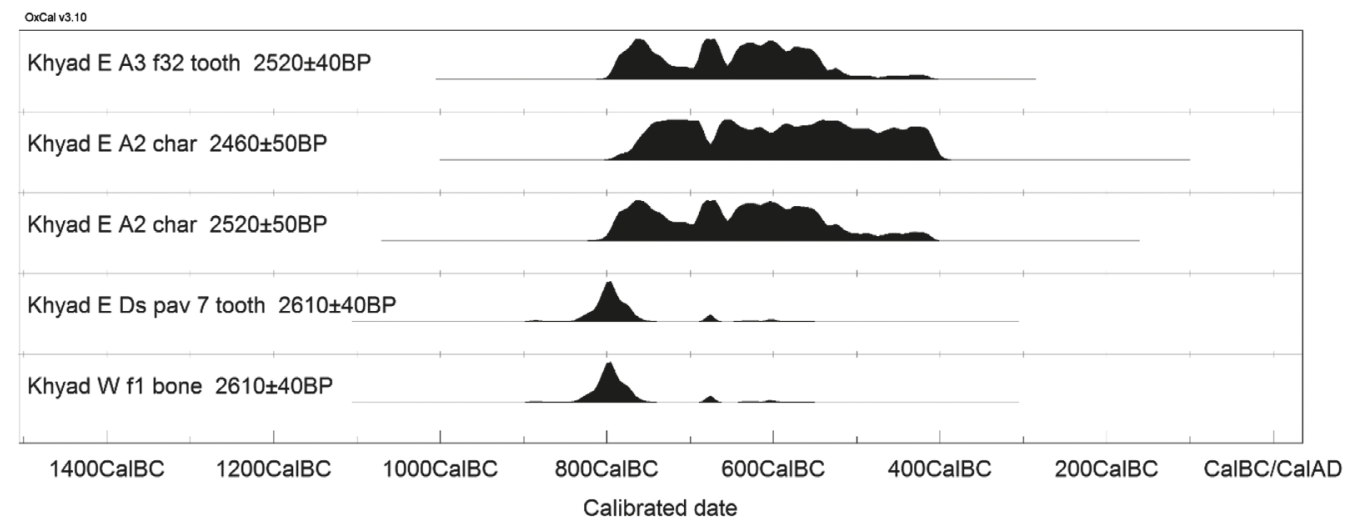

Fig. 6. Radiocarbon dates from Khyadag East and Khyadag West

cus for Early Iron Age copper production that destroyed most of the site's deer stones and added a Scythian feline motif to DS3.

Khyadag East was our first large excavation at a deer stone after Ulaan Tolgoi, and it revealed a complicated history. Findings include:

1) five large Eurasian Type III deer stones;

2) several miniature deer stones with Eurasian markings accompanied by small pavements and ritual bone deposits;

3) a pavement with butchered animal remains;

4) no hearth circles or prominent burials of horse heads;

5) dates of 800-400 BCE for both DSK and bronze components;

6) deer stone destruction;

7) Scythian coiled animal motifs on DS3.

These finds raise questions regarding the DSK-Iron Age transition. The absence of hearth circles and more than one or two horse mounds is unusual at DSK sites. Perhaps Khyadag East is a late expression of DSK ritual when miniature deer stones appeared, and horse sacrifices and hearth ritual was abandoned. The site was then disrupted by activity that toppled its deer stones, added a Scythian motif to DS3, and produced bronze with the aid of the site's inherent spiritual power. The poor resolution of the slag-associated charcoal dates from 800 to $400 \mathrm{BCE}$ leaves ample time for a close temporal association between the site's two components.

\section{Khyadag West}

Khyadag West (Fig. 7) is a few hundred meters west of Khyadag East. Surficial observation indicated both similarities and differences between the two sites: both lack khirigsuurs and horse mounds but had different styles of deer stone art. There were no miniature deer stones at Khyadag West, but unlike Khyadag East, it was surrounded by hearth rings.

Deer Stones Khydag West deer stones differ from Khyadag East in having three Type I stones and only one Type III stone (Fig. 8). DS1 (B39) is $3 \mathrm{~m}$ tall stone which has /// slashes on the face, deer images, pendant earrings, pitted necklace, mirror, and a belt band with 


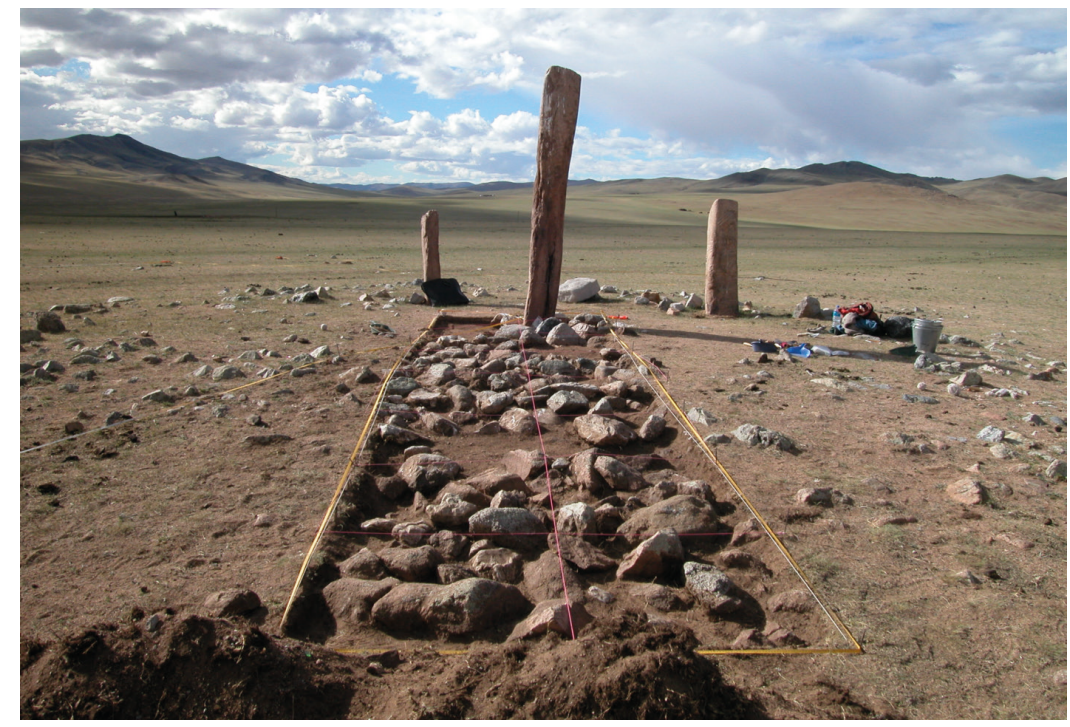

Fig. 7. Khyadag West with DS 2, 1, 4 (fallen), and 3, left to right. View northwest. Photo: W. Fitzhugh
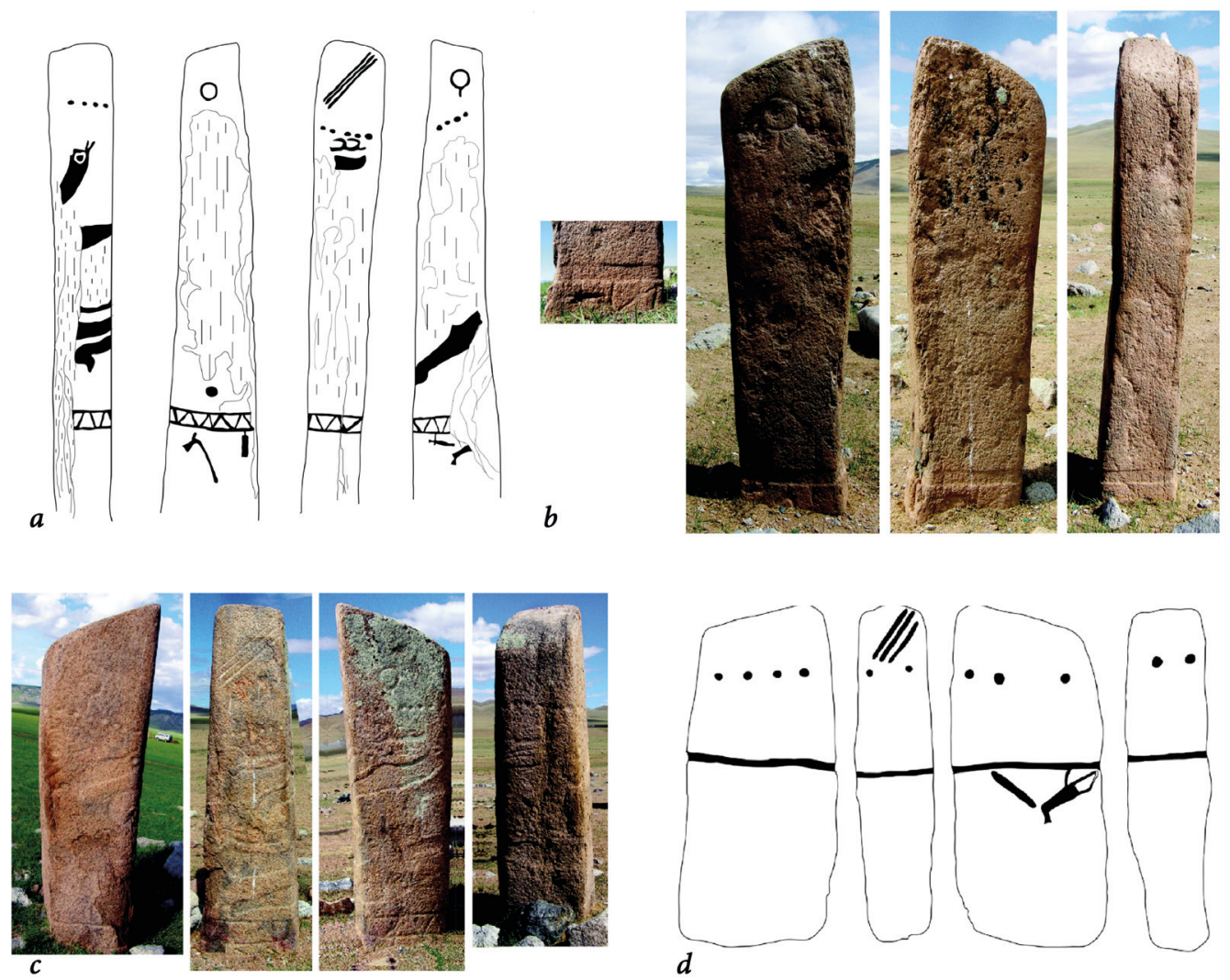

Fig. 8. Khyadag West Deer Stones 1-4: $a-$ DS1; $b$ - DS2, etc. Photos and graphics: J. Bayarsaikhan 
zig-zag decoration, axe, whetstone, knife, and gorytos. DS2 (B40) is too eroded to show more than earrings and a broad belt band. DS3 (B41) is the best preserved and shows a /// slash face, earrings with pendants, necklace pits, three deer wrapping around its four sides, and a belt decorated with a zig-zag design. DS4 (B42), a Eurasian stone that was lying on the surface, is $95 \mathrm{~cm}$ long, and has three face slashes, necklace pits, and a belt groove with a gorytos and an unidentifiable tool.

We mapped the site and excavated a $1 \times 8 \mathrm{~m}$ trench from DS1 to Feature 1 which seemed to be a horse mound but contained only a burned sheep skull (cal. 870-750 BCE). The rest of the trench yielded butchered bones but no artifacts. Fragments of a canid jaw, a small bronze knife blade, and a bronze button were found at the base of DS1. The only similarity between Khyadag West and its sister site is the absence of horse mounds and the presence of a Eurasian style DS4 that may have been a latter addition to the site during the middle DSK period.

\section{Zunii Gol}

Zunii Gol (Fig. 9) is a large DSK site south of the Delger Muren River at N $49^{\circ}$ $18.562^{\prime}$ / E 99 50.984'. V.V. Volkov made sketch maps ${ }^{21}$ and described its standing deer stones and khirigsuurs, one of which he excavated. The site was too large for us to map extensively in 2009, but we made drawings of the deer stones, mapped Area 4, excavated horse head features, and found an important undiscovered deer stone.
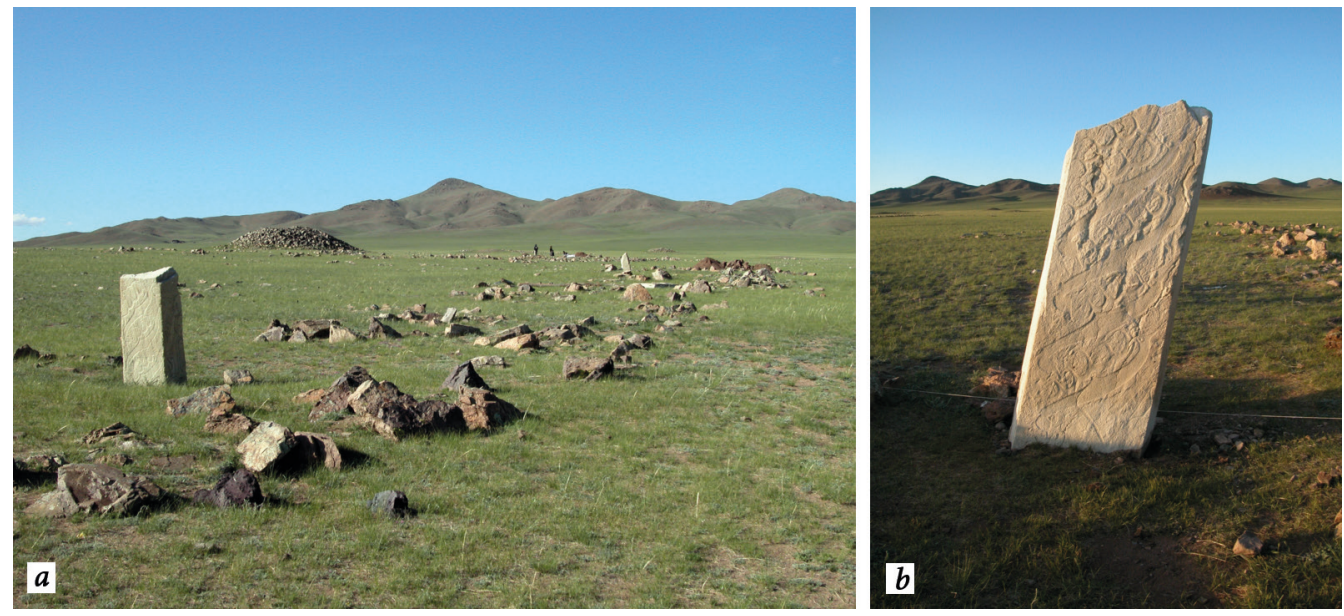

Fig. 9. Zunii Gol deer stone site showing: $a$ - deer stone alignment with horse features on east side; $b$ - south side of DS7. View north. Photos: W. Fitzhugh

Zunii Gol is an unusual site. Its deer stones are made from soft greenstone schist rather than from granite. While they have a profusion of Type I deer images, they have no face marks or belts, rare necklaces, and weapons float free as on the Sayan-Altai stones. Many stones have been broken and show evidence of impact marks. Its deer stones - like khirigsuurs - have horse mounds to their east (also seen at Khushuutiin Am and other

${ }^{21}$ Volkov V. V. Olennye kamni Mongolii. Fig. 80. 
sites), and there are rectangular pavements associated with some deer stones and khirigsuurs. Large khirigsuurs lie to the north of the deer stones, and some deer stones, which align at $040^{\circ} \mathrm{M}$ ), have horse mounds three or four times as large as usual, resembling small khirigsuur central mounds.

Zunii Gol Deer Stones. Volkov described seven deer stones that were standing or lying on the ground during his visit. Our work amplifies and adds to his descriptions (Fig. $10 a-g^{22}$ ). DS1 is $161 \mathrm{~cm}$ tall and has five right ascending deer and a tasseled earring with an adjacent smaller 'moon' circle, an axe on its south side, and four left ascending deer, a dagger, a bow, and a mirror on its north side. Four right ascending deer are on its narrow east side, and three deer ascend to the right on its west side above a pentagonal shield. DS2, which is $242 \mathrm{~cm}$ tall and missing its top, has three right ascending deer on its wider north and south sides, two ascending deer on its east side, and three right ascending deer and a shield on its west side. DS3, $202 \mathrm{~cm}$ above ground, has four ascending deer above two smaller deer at the bottom, and a mirror and a shield on one broad face, and four right ascending deer on the other broad face. One narrow side shows a right ascending deer above an axe. DS4 $(108 \mathrm{~cm})$ is $108 \mathrm{~cm}$ tall, with three ascending deer on one narrow side, three left ascending deer on the other narrow side, three right ascending deer above a floating axe, a dagger, and a knife on one wide side, and a single descending deer and a bow on the other wide side. DS5 $(244 \mathrm{~cm})$ is more elaborate: one wide face has six right ascending deer and an earring, and the other wide side has four large and two small left ascending deer. A narrow side features three left ascending deer with a mirror, and a rein hook at the bottom. There is no belt, but a necklace groove is present at the top. DS6 $(133 \mathrm{~cm})$ has three large and one small right ascending deer, an earring, and an axe at the bottom on one broad face, and three large left ascending deer and a dagger, a knife, and two barbed, feather-like forms at the bottom on the other wide side. Its narrow east-facing side has three left ascending deer, a barbed form and rein hook at the bottom, and a boar tooth on a necklace at the top. The narrow west side has two left ascending deer above a shield. DS7 $(204 \mathrm{~cm})$ has a steeply angled top with five left ascending deer, a mirror, a dagger, and a rein hook on its north side, and four right ascending deer and an axe, gorytos, and bow on its south side. The narrow east side has five left ascending deer and a long spear, and its narrow west side has three left ascending deer above a shield. Recent finds from Xinjiang include several miniature stone shields with chevrons identical to deer stone emblems at the Huahaizi No. 3 deer stone site of the Sandaohaizi culture in the Xinjiang ${ }^{23}$.

We uncovered and recorded three stones not known to Volkov at Zunii Gol. Deer Stone 8 (Fig. $10 h^{24}$ ), $271 \mathrm{~cm}$ long, with a broken top and damaged sides, has four right ascending deer, three small deer scattered around its top, and a gorytos, a bow, and shaft on one wide side, while the other wide side has two deer, one ascending left and the other descending left. DS9 (Fig. $10 i^{25}$ ) $191 \mathrm{~cm}$ long, was lying on the ground with three right ascending deer, a tasseled earring, a gorytos, and an axe on its south side, and on its north side - three left ascending deer, an earring and a small horse at the top, and a mirror, dagger, and knife. Its narrow east side has four right ascending deer below a necklace with

\footnotetext{
22 See: Bayarsaikhan J. Mongolyn umard nutgijn bugan hushuud. Fig. 106-112.

${ }^{23}$ Guo W. The Excavation of the Huahaizi... P. 151-162.

${ }^{24}$ See: Bayarsaikhan J. Mongolyn umard nutgijn bugan hushuud. Fig. 113.

25 See: Ibid. Fig. 114.
} 

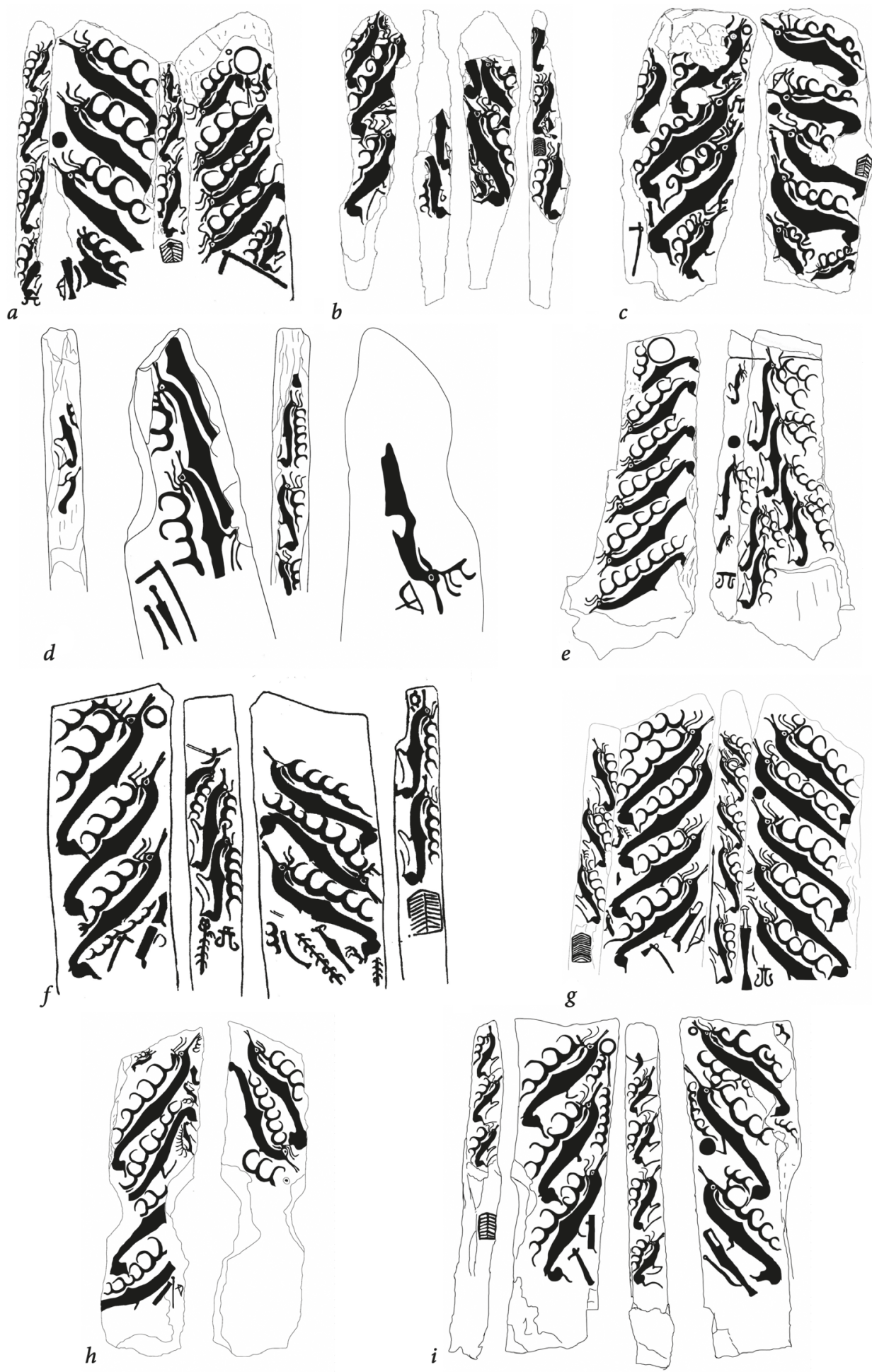

Fig. 10. Zunii Gol Deer Stones 1-9: $a$ - DS1; $b$ - DS2, etc. Graphics: J. Bayarsaikhan 

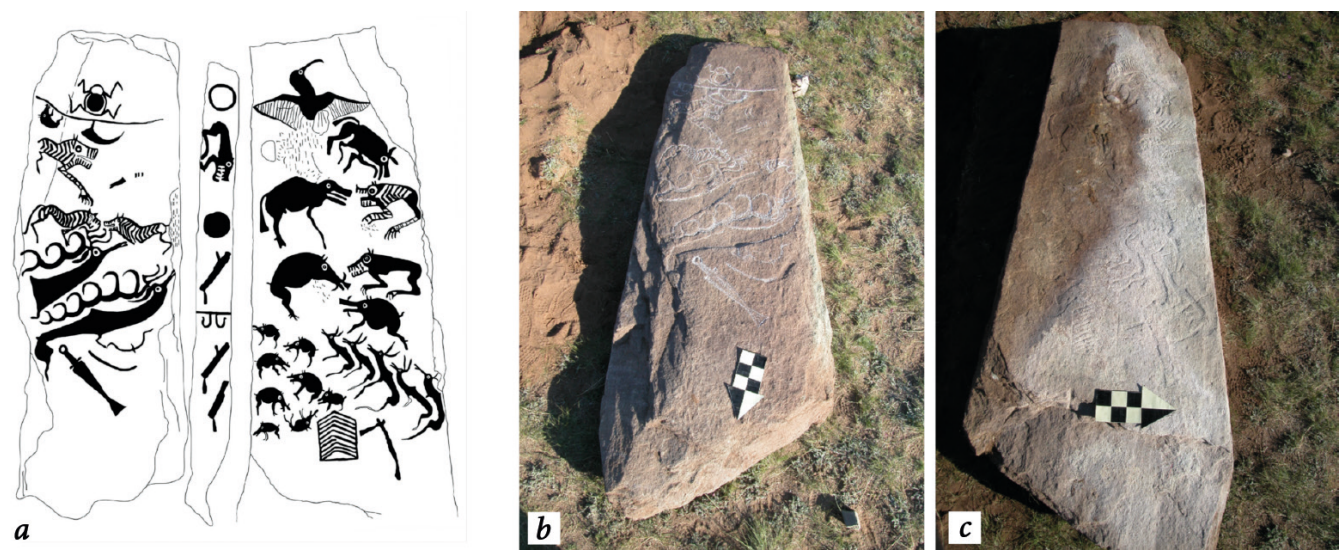

Fig. 11. Zunii Gol 'frog-ibisbill' DS10 showing: $a-$ a mix of DSK and narrative-style predatorprey Scytho-Saka elements, unlike all other deer stone art; $b$ - frog side; $c$ — "ibisbill” side. Graphics: J. Bayarsaikhan; photos: W. Fitzhugh

a suspended boar's tusk, and its narrow west side has three right ascending deer above a shield emblem.

Deer Stone 10. The absence of belts, the presence of free-floating implements, rare appearance of earrings and necklaces are common for Zunii Gol deer stones. Some of these features are also present on DS10 (Fig. $11^{26}$ ). This monument carries the most unusual carvings of any deer stone currently known in Mongolia. Measuring 248(l), 87(w) at its base, and $17(\mathrm{t})$, it was found at $\mathrm{N} 49^{\circ} 18.562^{\prime}$ / E $99^{\circ} 50.984^{\prime}$ where it had been broken from its base, and only a corner was visible above ground. The stone is made of chalky greenstone schist, and chips of this material were scattered in the surrounding soil.

At the top of the broad (original west) side is a depiction of an ibisbill, a bird with a long, down-curved bill and outstretched wings, shown presiding above a host of other animals. Below it, a striped tiger confronts two bovids with tufted tails, while another predator attacks two large boars. Below this are eight small boars and five left ascending deer without antlers; an axe; and a shield that identifies this as the stone's original west side. On the other broad east side, there are images of three striped felines confronting a prey (lost to erosion) above two Mongolian deer; a bow; dagger; and an unidentified implement that may be a horseman's crop. Presiding over this side above a necklace suspending a boar's tusk is a frog - an 'imperial' animal, according to Mongol beliefs as far back as Genghis Khan's time, and apparently in the Bronze Age. One narrow edge of the deer stone has a circular earring, and below that, in descending order: a predator, a mirror, a gorytos, a rein hook, and two more gorytos. The other narrow face was damaged and perhaps never had carvings.

Unlike other deer stones at Zunii Gol that display variations of the Type I deer stone with its formulaic tableau of Mongolian deer, DS10 includes carvings that illustrate animals, singly and in groups, interacting in a predator-prey narrative. In addition, this stone has a different organization and a new set of subjects. Like other Zunii Gol deer stones, it lacks face marks, a beaded necklace, embroidered or single-groove belt, suspended weap-

${ }^{26}$ See: Bayarsaikhan J. Mongolyn umard nutgijn bugan hushuud. Fig. 116. 
ons, and only shows a single earring and a necklace groove. It conforms to the general Mongolian Type I by including depictions of Mongolian deer, weapons, earrings, a mirror, and shield, but the deer are overshadowed by felines and pigs, and the weapons float unattached. Instead of a human face or slashes, there is a frog, and on the opposite side an ibisbill (Ibidorhyncha struythersii), a member of the ibis family, which inhabits riverbanks of the high Central Asian plateau. The stone's dominant visual theme is no longer a repetitive pattern of leaping deer, but instead dynamic illustrations of animals other than deer shown in predator-prey settings. Entirely missing is the standard structure and organization of Type I deer stones. We are at a loss to explain the significance of the ibisbill, but the frog has a deep history in Central Asia as a symbol of long, healthy, prosperous life, and of transformation, perhaps relating to rejuvenation as in lunar cycles.

The diverse subject matter, and the combination of absence of typical Mongolian Type I motifs, such as a broad patterned belt and beaded necklaces, and presence of earrings, mirrors, rein hooks, pentagonal emblems, and unattached weapons, and use of an irregular-shaped greenstone block, make Zunii Gol deer stones distinctive compared to most other sites in north-central Mongolia. In addition to these features, DS10 is chraracterised by even more unusual elements: its inclusion of narrative-style depictions that do not appear on any other deer stones in Mongolia but are a defining theme of Iron Age Scytho-Saka animal art. This, combined with other 'late' elements of DSK art, such as deer standing on "tiptoes" without folded legs, inclusion of other types of animals, and having weapons 'float' without belt attachment, supports the hypothesis that DS10 was created toward the end of the DSK period, during the Late Bronze Age-Iron Age transition, possibly pre-dating the Scythian-Saka animal style art horizon, or reflecting influence from these cultures. It is unfortunate we did not recover a sample for radiocarbon dating.

Fragments of two other deer stones were identified near DS10 in Area 3. DS11 was found a few meters west of the khirigsuur, and DS12 ${ }^{27}$ ten meters to the northwest of the mound beside a rock pavement. Both were too fragmented to interpret but indicated that other deer stones may have been present.

Zunii Gol Horse Head Excavations. We recovered radiocarbon samples from several horse mound features associated with Zunii Gol deer stones and khirigsuurs (see: List of Radiocarbon dates for Zunii Gol features). A feature 1 associated with DS7 (Fig. 12), southwest of the northernmost deer stones, was ringed by angular stone, while its center was filled with round stream cobbles. Beneath the cobbles was a horse head and six vertebrae touching the skull, with the atlas vertebra between the mandible branches. The four hoofs were in the usual 'anatomical' positions at the corners of the skull. Similarly to Khyadag East, Ushigiin Uver and other sites, rectangular boulder pavements are present at two Zunii Gol khirigsuurs where they probably were used for preparing animal sacrifices, if not for horse head ritual or hearth circles.

\section{List of radiocarbon dates for Zunii Gol features}

\begin{tabular}{llllll}
\hline Zunii Gol A1, F3 & Tumurbulag/2009 & B-272756 AMS & tooth coll. & $2870 \pm 40$ BP & BP 3140-3090 \\
Zunii Gol A2, DS4 & Tumurbulag/2009 & B-272757 AMS & tooth coll. & $2710 \pm 40$ BP & BP 2880-2750 \\
Zunii Gol A3, F1 & Tumurbulag/2009 & B-272758 AMS & tooth coll. & $2860 \pm 40$ BP & BP 3080-2870 \\
Zunii Gol K3, F42 & Tumurbulag/2009 & B-272759 AMS & tooth coll. & $2950 \pm 40$ BP & BP 3250-2980 \\
\hline
\end{tabular}

Note: B-272756 Zunii Gol A1, F3 has a second intercept at BP 3090-2870.

27 Bayarsaikhan J. Mongolyn umard nutgijn bugan hushuud. Fig. 115. 

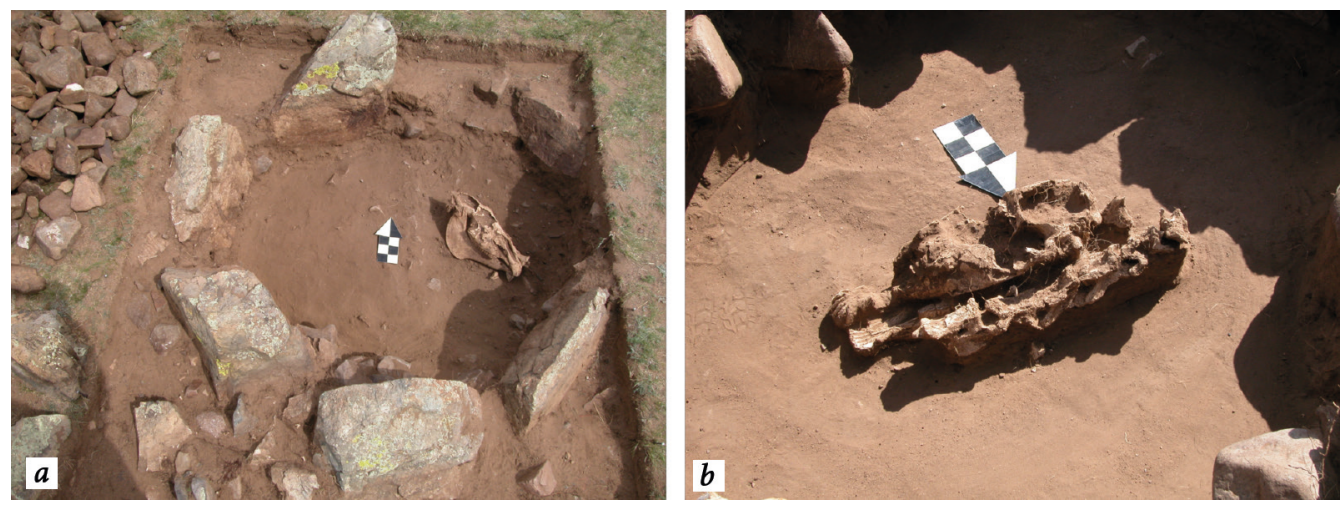

Fig. 12. Zunii Gol Area 1, Feature 3 with horsehead: $a$ - general view; $b$ - mandible with cervical vertebrae and hoof cores. Photos: W. Fitzhugh

Area 3. This area at the south end of the site contained DS10 and had an unusual khirigsuur surrounded by 105 stone features (Fig. 13). This mound was smaller than other Zunii Gol khirigsuurs and had no circular or rectangular stone fence, normally a defining khirigsuur characteristic. Thirty-three small horse head mounds were found east of the central mound, while nearly one hundred hearth rings were present to the west. The latter features follow the usual khirigsuur spatial pattern. However, in addition to the absence of a fence, this mound fails to follow other khirigsuur rules. Its easterly horse mounds are distributed radially in lines extending away from the central mound rather than being placed along its eastern side in concentric rings, while the hearth circles are arranged in a tight cluster instead of in concentric rings. These hearth rings are so close to each other that they could not all have been used at one time, and some rings were cannibalized for later hearths. In addition, DS10-12 were found within the khirigsuur precinct rather than located some distance away, thus following the pattern practiced in western Mongolia and southern Russia in contrast to central Mongolia. These distinctions and the presence of the unusual DS10, also displaying western features, suggests that Area 3 represents a modified DSK pattern compared with the rest of the site and requires further archaeological attention.

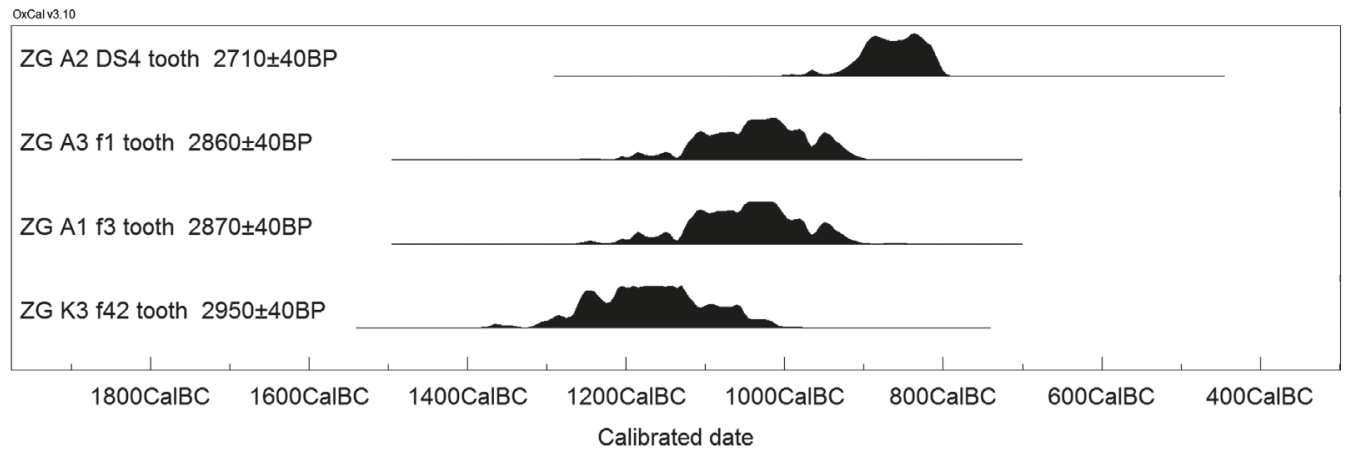

Fig. 13. Zunii Gol radiocarbon dates 
Dating Zunii Gol. Zunii Gol deer stones do not have ornamented belts, and only a few feature a belt groove. Many deer images have their legs extended, standing rather than springing. Tools 'float' unattached as in West Mongolian Sayan-Altai deer stones. The tops of most standing deer stones are broken (lightning strikes? ancient destruction?). Earrings are sometimes present, but slashes for faces are not. A few necklace lines are present but have no beads. Stylistically these features suggest a late phase of DSK deer stone art, as Volkov also believed. It was therefore with keen anticipation that we awaited the results of radiocarbon dates on Zunii Gol horse heads. As shown in List of radiocarbon dates for Zunii Gol features and Fig. 13, horse heads associated with Areas 1, 2 (Deer Stone 4), and 3 are virtually identical, falling in the middle of DSK chronology, while Khirigsuur 3 Feature 42 is the oldest. One could argue that the unusual features of Zunii Gol deer stones (absence of neck beads, wide, prominent textured belts, attached weapons, and presence of boar's tusks, 'floating' animals with more extended legs, and face slashes), might have been a function of something other than chronological age, for instance, resulting from regionally-based social or cultural differences within the DSK period. While this might be true, DS10 and the differences seen in Area 3 khirigsuur construction are likely a function both of chronology and regional cultural variation if not external intrusion. The Area 3 complex including DS10 probably date near the DSK-Square Burial transition ca 600 BCE but show clear western Pazyryk-Saka influence. DS10 carries stylistic elements of the Pazyryk/Scythian iconography while maintaining many aspects of the classic Type I/II Mongolian/Sayan-Altai deer stone tradition. Deer Stone 10 and Area 3 can be expected to date ca. cal. $2700-2500$ or later.

\section{Discussion and Conclusion}

Khyadag and Zunii Gol provide information for addressing issues that have emerged from a new generation of DSK studies.

Deer Stone Site Function and Organization. Most deer stone researches before 2000, due to the absence of artifact finds, was based on surficial survey and art historical studies. New research focusses on context and spatial patterns and explores deer stone memorials as part of the larger DSK complex as complimentary parts of the wider DSK ceremonial system $^{28}$. Excavations at Ulaan Tolgoi ${ }^{29}$ identified east-facing horse head burials as part of the ritual memorializing historical heroes represented by deer stones. In central Mongolia, khirigsuurs are often not directly associated with deer stones as they are in western Mongolia ${ }^{30}$

28 Takahama S., Hayashi T., Masanori K., Matsubara R., Erdenebaatar D. Preliminary Report of the Archaeological Investigations at Ulaan Uushig (UUushgiin Övör) in Mongolia. Kanazawa University (Japan) // Archaeological Bulletin. 2006. Vol.28. P.61-102; Kovalev A.A., Erdenebaatar D., Rukavishnikova I. V. Sostav i kompozitsiia sooruzhenii ritual'nogo kompleksa s olennymi kamniami Ushkiin-Uver (po rezul'tatam issledovanii 2013 goda) // Arkheologiia, etnografiia i antropologiia Evrazii. 2016. Vol. 44 (1). P. 82-92; Taylor W. T. T., Clark T. J., Bayarsaikhan J. et al. Early Pastoral Economies and Herding Transitions in Eastern Eurasia // Nature Scientific Reports. 2020. Vol. 10. P. 1001.

29 The Deer Stone Project; Fitzhugh W.W.: 1) Pre-Scythian Khirigsuurs... P.378-411; 2) Stone Shamans... P. 72-88; 3) The Mongolian Deer Stone-Khirigsuur Complex. P. 183-199.

30 Bayarsaikhan J. Mongolyn umard nutgijn bugan hushuud; Tishkin A. A. Advancing Archaeological Research... P. 453-478; Tishkin A.A., Shelenova E. B. Ob ispol'zovanii "olennykh" kamnei pri sooruzhenii tiurkskikh ogradok Mongol'skogo Altaia. Izvestiia Altaiskogo gosudarstvennogo universiteta. 2014. Vol. 4. P. 1-37. 
and in the Russian Altai and Sayan mountains ${ }^{31}$ where deer stones are part of khirigsuur construction. This suggests that the bodies of those represented by deer stones in Central Mongolia may be found in nearby khirigsuurs.

We also know from Ulaan Tolgoi and other sites that deer stones and khirigsuurs are often accompanied by large rectangular boulder pavements that probably were used for deer stone and khirigsuur ritual, and that identical ritual practices involving burials of horse heads and circle hearths are central aspects of deer stone and khirigsuur ceremonialism. In both cases, horse features tend to be found east of deer stones and khirgsuurs, while hearth circles are found on the west side. Khirigsuurs 'face' east as shown by their east-side entrances and horse head mounds. It has been suggested that khirigsuurs were conceived as symbolic chariots whose 'horses' carried the deceased toward the rising $\operatorname{sun}^{32}$. Other settlement features found at deer stones and khirigsuurs contain animal bones, ceramics, and hearths for preparing ritual meals. In addition to a deer stone occupation, Khyadag East also had a post-DSK copper production use that may have benefitted from the site's status as a deer stone location. In short, excavation reveals that deer stone sites have complex histories that can only be explored by excavation.

Deer Stone Types and Distribution. Khyadag and Zunii Gol bring new understanding about the meaning, geography, and chronology of Volkov's deer stone types. Khyadag East with its full-size and miniature Type III (Eurasian) deer stones is anomalous in central Mongolia where Type I deer stones predominate. Its dates of 800-400 BCE reveal its occupation in the latter part of the DSK period, overlapping with the Early Iron Age. Its undated miniature deer stones indicate that Type III stones are not restricted to western Mongolia, southern Russia, and other western regions and should not be named "West Eurasian". Perhaps over time, DSK society began to expand the concept of deer stone memorials to a wider class of people, using simpler stones. Evidence from northern Mongolian sites such as Avt Mod, Targon Nuur, and others show that Type III stones are common within the Type I area and are not limited to western Mongolia or 'Eurasia'. Type II Sayan-Altai stones are also known in central Mongolia and may also be a later stylistic development utilizing unattached 'free-floating' weapons and a wider cast of animals (horses, pigs, felines), and Mongolian deer on 'tiptoe' with legs extended. So far, Type II and III stones have not been dated by radiocarbon.

Volkov's Types II and III are not restricted to the Sayan, Altai, or Western Eurasia but also occur in central Mongolia, making their geographic names problematic. However, his three types continue to have general internal consistency, although within the types there is considerable variation. Types II and III are probably late in the DSK tradition and overlap chronologically with Type I Mongolian deer stones. Dating these types and refining their classification and distributions should be a research priority and, in the absence of horse heads, can be accomplished with charcoal from circle hearths.

Zunii Gol offers perspective on style variation of Type I deer stones. While its deer stones other than DS10 follow the Type I format, they lack belts, necklaces, and face slashes,

31 Chugunov K., Parzinger H., Nagler A. Der skythische Fürstengrabhügel von Aržan 2 in Tuva. Vorbericht der russisch-deutschen Ausgrabungen 2000-2002 // Eurasia Antiqua. 2003. Vol. 9. P. 113-162.

32 Khudiakov Y. S. Khereksury i olennye kamni // Arkheologiia, Etnografia i Antropologiia Mongolii. Novosibirsk, 1987. P. 136-162; Lepetz S., Zazzo A., Bernard V. et al. Customs, rites, and sacrifices relating to a mortuary complex in Late Bronze Age Mongolia (Tsatsyn Ereg, Arkhangai) // Anthropozoologica. 2019. Vol. 54 (15). P. 151-177. 


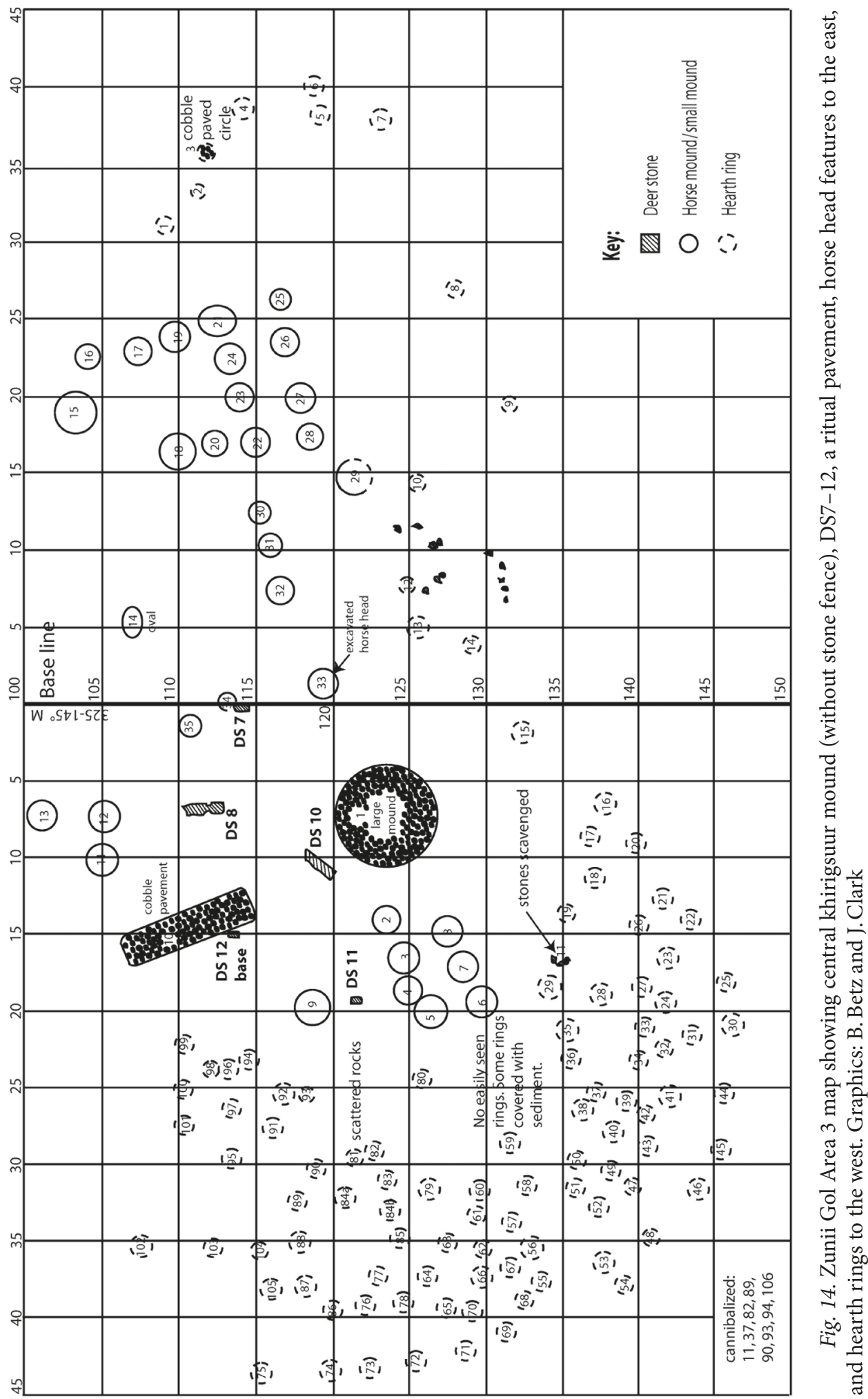


and many have irregular shapes and are poorly finished. These differences from highly standardized, well-finished Type I stones from the large central Mongolian sites may reflect regional cultural differences, later chronology, or perhaps a lack of skilled craftsmen or high-quality quarry stone. DS10 stands out as the 'wild card' among other Zunii Gol deer stones. DS10 and the unusual Area 3 khirigsuur suggests a departure from DSK tradition resulting from a site-unit intrusion or Scytho-Saka influence at the transition from Late Bronze to Early Iron Age.

\section{Preservation and the Future of Deer Stone Studies}

After 3000 years of exposure to climatic extremes, Mongolia's deer stones - its most ancient and iconic standing monuments - face an uncertain future. Despite having been dated accurately to cal. 3300-2700 BP, their origin remains mysterious; their regional and chronological styles need analysis; their relationship with West Eurasian deer stones requires study ${ }^{33}$; and their role in the development of Scytho/Saka/Pazyryk art should be clarified. Yet concurrent with increased scholarly attention and awareness of their role as an iconic Mongolian national symbol, and a focus of tourist attraction, their physical existence is threatened as never before. Traditional sources of damage like weathering, frost-spalling, lightning strikes, animal rubbing, and lichen and plant encroachment continue. Modern conditions have brought new agents of despoliation including graffiti, defacement, theft, and destruction of site contexts. Today the latter impacts dwarf the cumulative damage of the past three millennia. Because DSK domestic sites are nearly invisible archaeologically, much of what can be learned about this classical era will come from its memorial and mortuary sites. Consequently, more attention must be given to protecting and preserving these iconic treasures of Mongolia's past.

\section{References}

Bayarsaikhan J. Mongolyn umard nutgijn bugan hushuud. Ulaanbaatar, Interpress Publ., 2017, 323 p. (In Mongolian)

Bayarsaikhan J. Research issues on Ritual Component of Deer Stones and Khirigsuurs. Nomadic heritage Studies. Museum Nationale Mongoli, t. IX, fasc. 6. Ulaanbaatar, [s.n.], 2009, pp.41-62.

Beaubien H.F., Karas B.V., Fitzhugh W. Documenting Mongolia's Deer Stones: Application of ThreeDimensional Digital Imaging Technology to Preservation. Scientific Research on the Sculptural Arts of Asia. Washington, Archetype Publications and Freer Gallery of Art, Smithsonian Institution, 2007, pp. 133-142.

Broderick L. G., Houle J.-L., Seitsonen O., Bayarsaikhan J. The Mystery of the Missing Caprines: Stone Circles at the Great Khirigsuur in the Khanuy Valley. Studia Archaeologica, 2014, vol. XXXIV, pp. 164-174.

Chlenova N. L. Olennye kamni kak istoricheskii istochnik. Novosibirsk, Nauka Publ., 1984, 98 p. (In Russian)

Chugunov K., Parzinger H., Nagler A. Der skythische Fürstengrabhügel von Aržan 2 in Tuva. Vorbericht der russisch-deutschen Ausgrabungen 2000-2002. Eurasia Antiqua. 2003, vol.9, pp. 113-162.

Dikov N. N. Bronzovyi vek Zabaikal'ia. Ulan-Ude, BKNII SO AN SSSR Press, 1958, 146 p. (In Russian)

Esin Y. N., Magail J., Rousseliere H., Walter P. Les peintures dans l'art pariétal de la culture Okuniev. Bulletin du Musée d’Anthropologie préhistorique de Monaco, 2014, no. 54, pp. 163-183.

Fitzhugh W. W. Mongolian Deer Stones, European Menhirs, and Canadian Arctic Inuksuit: Collective Memory and the Function of Northern Monument Traditions. Journal of Archaeological Method and Theory, 2014, vol. 24 (1), pp. 149-187. https://doi.org/10.1007/s10816-017-9328-0

${ }^{33}$ See: Olkhovskii V. S. Monumental'naia skul'ptura... 
Fitzhugh W.W. Pre-Scythian Khirigsuurs, Deer Stone Art, and Bronze Age Cultural Intensification in Northern Mongolia. New Directions in Steppe Archaeology: the Emergence of Complex Societies in the Third to First Millennium BCE. Cambridge, Cambridge University Press, 2009, pp.378-411.

Fitzhugh W. W. Stone Shamans and Flying Deer of Northern Mongolia: Deer Goddess of Siberia or Chimera of the Steppe? Arctic Anthropology, 2009, vol. 46 (1-2), pp. 72-88.

Fitzhugh W. W. The Mongolian Deer Stone-Khirigsuur Complex: Dating and Organization of a Late Bronze Age Menagerie. Current Archaeological Research in Mongolia. Bonn, Vor- und Fruhgeschichtliche Archeologie, Rheinische Friedrich-Wilhelms-Universitat, 2009, pp. 183-199.

Fitzhugh W.W., Bayarsaikhan J. Mapping Ritual Landscapes in Bronze Age Mongolia and Beyond: Interpreting the Ideoscape of the Deer Stone-Khirigsuur Complex. Mapping Mongolia: Situating Mongolia in the World from Geologic Time to the Present. Philadelphia, University of Pennsylvania Press, 2005, pp. 166-192.

Gryaznov M.P. Monumental'noe iskusstvo na zare skifo-sibirskikh kul'tur v stepnoi Azii. Tezisy konferentsii "Kontakty i vzaimodeistviia drevnikh kul'tur". Leningrad, AN SSSR Press, 1981, pp. 21-24. (In Russian)

Guo W. The Excavation of the Huahaizi No. 3 Site in Qinghe County, Xinjiang. Chinese Archaeology, 2017, vol. 17 (1), pp. 151-162.

Hatakeyama T. The Tumulus and Stag Stones at Shiebar-kul in Xinjiang, China. Newsletter of Steppe Archaeology, 2002, vol. 13, pp.1-8.

Jacobson E. Petroglyphs and the Qualification of Bronze Age Mortuary Archaeology. Archaeology, Ethnology, and Anthropology of Eurasia, 2002, vol. 3 (11), pp. 32-47.

Jacobson E. The Deer Goddess of Ancient Siberia: A Study in the Ecology of Belief. Leiden, New York, Kuhn, E. J. Brill, 1993, 296 p.

Jacobson-Tepfer E. Cultural Riddles: Stylized Deer and Deer Stones of the Mongolian Altai. Bulletin of the Asian Institute, New Series, 2001, vol. 15, pp.31-56.

Jacobson-Tepfer E. The Hunter, the Stag, and the Mother of Animals: Image, Monument, and Landscape in Ancient North Asia. Oxford, Oxford University Press, 2015, 448 p.

Jettmar K. Body-Painting and the Roots of the Scytho-Siberian Animal Style. The Archaeology of the Steppes: Methods and Strategies. Series minor. 1994, vol. 44, pp.3-15.

Khudiakov Y. S. Khereksury i olennye kamni. Arkheologiia, Etnografia i Antropologiia Mongolii. Novosibirsk, Nauka Publ., 1987, pp. 136-162. (In Russian)

Kovalev A.A., Erdenebaatar D., Rukavishnikova I.V. Sostav i kompozitsiia sooruzhenii ritual'nogo kompleksa s olennymi kamniami Ushkiin-Uver (po rezul'tatam issledovanii 2013 goda). Arkheologiia, etnografiia i antropologiia Evrazii, 2016, vol. 44 (1), pp. 82-92. (In Russian)

Kubarev V.D. Dva izvaianiia epokhi bronzy v Gornom Altae. Arkheologiia, etnografiia i antropologiia Evrazii, 2009, vol. 37 (1), pp. 34-38. (In Russian)

Lepetz S., Zazzo A., Bernard V., de Larminat S., Magail J., Gantulga J.-O. Customs, rites, and sacrifices relating to a mortuary complex in Late Bronze Age Mongolia (Tsatsyn Ereg, Arkhangai). Anthropozoologica, 2019, vol. 54 (15), pp. 151-177.

Magail J. Les stèles ornées de Mongolie dites 'pierres à cerfs', de la fin de lâge du Bronze. In: Statues-menhirs et pierres levées du Néolithique à aujourd'hui. Saint-Pons-de-Thomières, Direction régionale des affaires culturelles Languedoc-Roussillon Groupe Archéologique du Saint-Ponais, 2015, pp. 89-101.

Miniaev S. On the Interpretation of Certain Images on Deer Stones. Silk Road, 2013, vol. 11, pp.54-59.

Naiden F.S. Smoke Signals for the Gods: Ancient Greek Sacrifice from the Archaic through Roman Periods. Oxford, New York, Oxford University Press, 2013. 442 p.

Novgorodova E. A. Drevniaia Mongoliia (nekotorye problemy khronologii i etnokul'turnoi istorii). [Ancient Mongolia]. Moscow, Nauka Publ., 1989, 384 p. (In Russian)

Okladnikov A. P. Olennyi kamen s reki Ivolgi. Sovetskaia arkheologiia, 1954, vol. 19, pp. 207-220. (In Russian)

Olkhovskii V.S. Monumental'naia skul'ptura naseleniia zapadnoi chasti evraziiskikh stepei epokhi rannego zheleza. Moscow, Nauka Publ., 2005, 256 p. (In Russian)

Polosmak N.V. Tatuirovka u pazyryktsev. Arkheologiia, etnografiia i antropologiia Evrazii, 2000, vol. 4 (4), pp. 95-102. (In Russian)

Rudenko S. I. Kul'tura naseleniia gornogo Altaia v skifskoe vremia. Moscow, Leningrad, AN SSSR Press, 1953, 402 p. (In Russian) 
Savinov D. G. Olennye kamni v kul'ture kochevnikov Evrazii. St. Petersburg, St. Petersburg University Press, 1994, 208 p. (In Russian)

Takahama S., Hayashi T., Masanori K., Matsubara R., Erdenebaatar D. Preliminary Report of the Archaeological Investigations at Ulaan Uushig (UUushgiin Övör) in Mongolia. Kanazawa University (Japan). Archaeological Bulletin, 2006, vol.28, pp.61-102.

Taylor W. T. T., Clark T. J., Bayarsaikhan J., Tuvshinjargal T., Thompson J., Jobe W., Fitzhugh W., Kortum R., Spengler R.N., Shnaider S., Seersholm F.V., Hart I., Case N., Wilkin S., Hendy J., Thuering U., Miller B., Miller A.R. V., Picin A., Vanwezer N., Irmer F., Brown S., Abdykanova A., Shultz D. R., Pham V., Bunce M., Douka K., Jones E. I., Boivin N. Early Pastoral Economies and Herding Transitions in Eastern Eurasia. Nature Scientific Reports, 2020, vol.10, p.1001. https://doi.org/10.1038/s41598020-57735-y

Taylor W. T., Wilkin S., Wright J., Dee M., Erdene M., Clark J., Tuvshinjargal T., Bayarsaikhan J., Fitzhugh W., Boivin N. Radiocarbon Dating and Cultural Dynamics Across Mongolias Early Pastoral Transition. PLOS ONE, 2019, vol. 14 (11). Article-e0224241

Tishkin A. A. Advancing Archaeological Research of the Mongolioan Altai through the Scientific Study of Deer Stones: New Discoveries from Buyant Valley. Asian Perspectives, 2020, vol. 59 (2), pp. 453-478.

Tishkin A.A., Shelenova E.B. Ob ispol'zovanii “olennykh" kamnei pri sooruzhenii tiurkskikh ogradok Mongol'skogo Altaia. Izvestiia Altaiskogo gosudarstvennogo universiteta, 2014, vol.4, pp. 1-37. https:// doi.org/10.14258/izvasu(2014)4.1-37. (In Russian)

Tseveendorj D. Some Deer Stone Stelas found in Mongolia. Studia Archeologica, 1979, t. VII, fasc. 13, pp. 3685.

Tsybiktarov A. Tsentral'naia Aziia v epokhu bronzy i rannego zheleza (problemy etnokul'turnoi istorii Mongolii i Iuzhnogo Zabaikal'ia serediny II — pervoi poloviny I tys. do n. e.). Arkheologiia, etnografiia i antropologiia Evrazii, 2003, vol. 13, pp. 80-97. (In Russian)

Turbat T., Bayarsaikhan J., Batsukh D., Bayarkhuu N. Jargalantyn amny bugan khushuud = Deer Stones of Jargalant Am. Ulaanbaatar, NOMKHUR Publ., 2011, 192 p. (In Mongolian and English)

Van Straten F. T. Hierà Kalá: Images of Animal Sacrifice in Archaic and Classical Greece. Leiden, E. J. Brill, 1995, $374 \mathrm{p}$.

Volkov V. V. Early Nomads of Mongolia. Nomads of the Eurasian Steppes in the Early Iron Age, Berkeley, University of California Press, 1995, pp. 319-332.

Volkov V. V. Olennye kamni Mongolii. Moscow, Scientific World Publ., 2002, 248 p. (In Russian)

Volkov V.V., Novgorodova A.E. Olennye Kamni UUushgiin Overa (Mongolia). Pervobytnaia arkheologiia Sibiri. Leningrad, 1975, pp. 78-84. (In Russian)

Watson J., Goodman M., Speakman J. Slag Report for Finds from 2008 Deer Stone Project Field Season. Project no. 6249. Smithsonian Museum Conservation Institute. Appendix 1. 2009 Mongolia Field Report. Washington, Arctic Studies Center. National Museum of Natural History, Smithsonian Institution, 2009, pp. 211-218. 